\title{
No Diffusion at All: Trade, Free Riding, and Government Underspending in Environmental Innovation
}

\author{
Muzhou Zhang ${ }^{1}$ \\ Department of Government, University of Essex \\ muzhou .zhang@essex.ac.uk
}

May 19, 2021

\begin{abstract}
Governments have an irreplaceable role in supporting environmental innovation due to market failure. Nevertheless, this article develops the free riding argument that the tradedriven technology transfer incentivizes national governments to underspend on environmental innovation. The data on government environmental research and development (R\&D) expenditures and bilateral trade volumes of environmental goods from 32 OECD countries, 1982-2017, are used to substantiate my argument. Spatial regression finds that nations spend less on environmental R\&D as a response to the increasing spending from their trade partners in the preceding year. This research contributes to the broader literature by presenting a new mechanism underlying the trade-environment nexus and showing that the strengthening transnational interdependence does not necessarily drive norms and policies to diffuse internationally.
\end{abstract}

1. I am grateful to Zorzeta Bakaki, Tobias Böhmelt, Federica Genovese, Howard Liu, and the participants at the Essex PhD IR workshop for valuable comments. All errors are my own. 


\section{Introduction}

Innovation is a fundamental yet economically feasible green solution, but its pace considerably lags behind the global environmental urgency. For instance, the renewable share in the world's total primary energy consumption only increased from 6 to 11 percent in the past half-century (BP PLC 2020), whereas the annual carbon dioxide emission rocketed from 11 to 37 billion tonnes during the same period (Our World in Data, n.d.). The International Renewable Energy Agency estimates that until 2050, an additional US\$ 27-trillion investment in low-carbon technologies is needed to ensure a global green transition (IRENA 2018). ${ }^{1}$ However, the private sector hardly can spontaneously fill the funding gap that environmental innovation faces. On the global bond market, for example, only one percent fund flows to green projects (OECD 2018). Due to market failure, governments have an irreplaceable role in supporting environmental innovation (Acemoglu et al. 2012; Acemoglu et al. 2016; Fischer, Preonas, and Newell 2017). To meet the Paris Agreement target, the worldwide government research funding for environmental technologies has to grow at least twofold (Dechezleprêtre, Martin, and Bassi 2019).

Nevertheless, this article develops the argument that national governments tend to strategically underspend on environmental innovation. Progressively making environmental investment exposes governments to political costs for various reasons, including the political turmoils after innovation failures (a notable case is the bankruptcy of Solyndra LLC) and voters' distrusts regarding the worthiness of such spending (Abou-Chadi and Kayser 2017; Gailmard and Patty 2019). Meanwhile, since international trade is the foremost channel for technology transfer (e.g., Keller 2004), trade connections between countries realize the positive externality of government spending on environmental innovation-one country invests, all countries benefit. Therefore, with both an internal motive and an external incentive, nations tend to free ride off the government spending on environmental innovation made by their trade partners rather than making sufficient investments by themselves.

I employ the data on government environmental R\&D spending and bilateral trade volumes of environmental goods from 32 OECD countries, 1982-2017, to substantiate my argument. Spatial regression finds that nations spend less on government environmental R\&D as a response to the increasing spending from their trade partners in the preceding year. A dis-

\footnotetext{
1. See OECD, The World Bank, and UN Environment (2018) for an overview regarding the financing shortage in environmental innovation.
} 
aggregated, country-specific analysis further reveals that such worrying free riding is seen among all nations, including the leading green innovators such as Japan, Germany, and the United States.

A wide array of government practices for environmental protection, such as institutionalizing environmental agencies, enforcing end-of-pipe regulations, implementing market-pull policies, and mandating information disclosures, are found to become increasingly popular among different governments once they are adopted by first-movers at first (Holzinger, Knill, and Sommerer 2008; Kern, Jörgens, and Jänicke 2001). But such dissemination-driven popularity is not seen in a a single yet important case: direct government funding for environmental innovation (Dechezleprêtre, Martin, and Bassi 2019; Grafström et al. 2020; Zachmann, SerwaahPanin, and Peruzzi 2015). This article provides a strategic explanation to this alarming puzzle by showing that national governments underspend on environmental innovation since such spending is subjective to their tendency to free ride. An important policy implication is that more international coordination prior to the end-of-pipe and technology deployment stages is urgently needed to better, faster address the global environmental crisis.

This article contributes to the broader literature in two frontiers. First, it presents a new mechanism underlying the contentious trade-environment nexus. The pollution heaven hypothesis is built on the pollution-embodied North-South trade (Copeland and Taylor 1994) while the pursuit of trade share drives environmental regulations in different countries to a race-to-the-bottom (Cary 1974). In the opposite side, the "California effect" suggests that the greener markets in developed nations stimulate the export-oriented developing countries to voluntarily improve their own environmental standards. In contrast to these established theses, I show that trade can adversely affect global environmental protection by eliciting nations to free ride off their trade partners' environmental efforts. My article therefore richens the scholarship on trade's complex and consequential environmental implication. Also, my research broadens the scope of the literature by shifting the focus from the Norht-South trade or South-South competition to the trade between the Global North nations.

Second, this article shows under which condition the influential diffusion theory in political science does not hold. The strengthening transnational interdependence, such as the growing trade flows and the expanding international organizations, is theorized to push norms and policies to diffuse across different countries because of socialization (Finnemore and Sikkink 1998), learning (Bennett 1991; Rose 1991), and market mechanism (Vogel 1995, 1997). A num- 
ber of previous studies indeed corroborate the diffusion of environmental norms and policies through trade connectivity (e.g., Baldwin, Carley, and Nicholson-Crotty 2019; Holzinger, Knill, and Sommerer 2008; Ward and Cao 2012), whereas I show that such diffusion ceases to exist—and even flips around to divergence-when what one nation does has a spillover effect on others. Despite that both convergence and divergence are theoretically possible directions of the cross-national interdependence of state behaviors and government policies (Neumayer and Plümper 2016), the previous studies, with a few notable exceptions (Aklin 2016; Böhmelt and Freyburg 2015; Franzese and Hays 2006), disproportionately more focus on how closely connected countries become similar to each other on these political outcomes (convergence) while paying insufficient attention to the alternative-how closer countries become dissimilar (divergence). My finding on the cross-national divergence of government environmental efforts suggests scholars to not simply considering convergence as a default interdependence direction, which may hinder or confound substantive findings.

\section{Theory}

\section{The Transnational Interdependence of Environmental Norms and Policies}

State behaviors and government policies across different countries are mutually influenced. A prominent example of such interdependence is the transnational diffusion of environmental norms and policies. Beise and Rennings (2005), Huber (2008), Jänicke and Jacob (2004), and Kern, Jörgens, and Jänicke (2001) provide the detailed qualitative and descriptive evidence showing that once new environmental policy instruments are implemented by first-movers, how quickly and widely are they to spread to other countries. Drawing from several case studies, Tews, Busch, and Jörgens (2003) conclude that it is diffusion rather than self-innovation that contributes to the increasing adoption of carbon taxes, environmental disclosure mandates, and centralized sustainable development plans by different governments. Holzinger, Knill, and Sommerer (2008) and Ward and Cao (2012) use quantitative data to corroborate this conclusion and further find that international organizations are an influential diffusion driver.

Beyond international organizations, in which nations can learn from others, international trade is found an equally important channel that diffuses environmental norms and policies. In consistency with what the "California effect" suggests, Potoski and Prakash (2005), Prakash and Potoski (2006, 2007), Saikawa (2013), and Zeng and Eastin (2007) all find that a country 
voluntarily adopts higher regulatory standards in environmental protection when the country primarily exports to, or receives investments from, greener nations. These findings on the trade-embodied environmental enforcements, to some degree, nullify the prevalent pollution heaven hypothesis, which posits that the North-South trade causes the environmental degradation in developing countries. Other than the invisible market mechanism, first-movers in environmental protection also straightforwardly state their environmental preferences and try to translate them to actual actions of their trade partners. In this regard, Bastiaens and Postnikov (2017), Brandi et al. (2020), and Jinnah and Lindsay (2016) show that the environmental provisions in preferential trade agreements improve developing countries' environmental performance on various aspects.

\section{Trade and Free Riding on Governement Environmental Innovation Spending}

Despite that the previous empirical studies largely agree that the increasing trade connectivity is associated with environmental improvement, in what follows, I develop the argument that political costs motivate and importantly, trade incentivizes national governments to strategically underspend on environmental innovation, which substantially brings a negative impact on the prosoect of global green transition (Acemoglu et al. 2012; Acemoglu et al. 2016; Zachmann, Serwaah-Panin, and Peruzzi 2015). Progressively supporting environmental innovation is politically costly for governments due to the possible political turmoils after innovation failures. The case of Solyndra LLC illustrates this cost. The energy start-up company received a 535-million federal grant from the Obama Administration but then soon went into bankruptcy in the end of 2011, just a year ahead of the 2012 presidential election. Seeing Solyndra's collapse as an electoral opportunity, Obama's opponents launched an 18-month investigation in Congress $^{2}$ and spent six millions on advertisements against the president's mishandling on the issue. ${ }^{3}$

Actively investing in environmental innovation is too likely to bring direct electoral punishment for governments. Green transitions necessarily undermine some carbon-dependent sectors, so the voters who rely on them naturally penalize the incumbents who steadily fund environmental technologies (Bechtel, Genovese, and Scheve 2019). Since the facilities of re-

\footnotetext{
2. Reuters, August 27, 2012. https://www.reuters.com/article/solyndra-bankruptcy/ solyndra-backers-could-reap-big-tax-breaks-u-s-wants-details-idUSL1E8JRFCV20120827, accessed May 19, 2021.

3. The Wall Street Journal, January 14, 2012. https://www.wsj.com/articles/BL-WB-33080, accessed May 19, 2021.
} 
newable energy or pollution abatement inevitably bring some adverse impacts to the local communities, such electoral punishment is also used by the constituents from the adverselyaffected areas (Stokes 2016). Beyond electoral backlash from certain groups, governments are also found to face negative electoral consequences when their environmental expenditures are deemed as unnecessary by voters, especially during economic downturns (Abou-Chadi and Kayser 2017). Gailmard and Patty (2019) formalize how voters' distrusts on environmental protection measures hinder governments from fulfilling their green responsibilities. Specifically, Gailmard and Patty analytically derive the equilibrium that when both the effectiveness of prevention measures, e.g., investing in environmental innovation to preempt disastrous environmental outcomes in the future, and honesty are both private information to politicians, rational voters punish the politicians who spend more on prevention. Any tangible benefits of funding environmental technologies will only realize after a longtime. By contrast, though, the incumbents immediately bear all costs. So, time horizon-constraint governments inherently hesitate to progressively support environmental innovation (Cao and Ward 2015; Wright 2008).

With an internal motive, national governments are further incentivized to strategically underspend on environmental innovation because such spending has an positive externalityone country invests, all countries benefit. This positive externality exists because new technologies travel across borders with or without the notice of innovators. Coe and Helpman (1995) and Coe, Helpman, and Hoffmaister (1997), among others, find that a nation's domestic R\&D input significantly increases total factor productivity, a often-used indicator for technology-empowered economic output, in other nations. This relationship evidently shows the large-scale and consequential impact that international technology transfer has. A consensus among scholars, policy makers, and practitioners is that international trade in goods and services is the foremost catalyst for technology transfer, followed by other transnational economic connections including FDI, licensing, joint venture, and so on (Maskus 2004). Wacziarg (2001) provides strong evidence in support of this view by discovering a positive relationship between trade liberalization and technology transfer between different countries. ${ }^{4}$ Through international trade, a country can straightforwardly apply the purchased materials, equipment, and methods to upgrade its existing production processes technologically. It can also acquire technological information embodied in the directly traded products by imitating or revere- 
engineering.

When it comes to environmental innovation specifically, Dechezleprêtre et al. (2011) find that from the late 1970s to early 2000s, the global export rate of green inventions climbed from 10 to 30 percent with an accelerating trend. Drawing from the case studies on pollution mitigation measures and photovoltaics, Lanjouw and Mody (1996) and De La Tour, Glachant, and Ménière (2011) conclude that it is trading on related products rather than domestic R\&D that propels a nation's later environmental technological advancements. Perkins and Neumayer (2009) show that a country's carbon efficiency increases as a result of the deepening trade relationships with the carbon-efficient economies, indicating that trade substantially enables environmental technologies elsewhere to empower a country's own environmental innovation. Overall, the spillover rate of low-carbon technologies is greater than that of high-carbon technologies (Dechezleprêtre and Sato 2017), so government spending on environmental technologies also has a larger positive externality than on other technologies. It is intuitive to expect that the cross-border transfer of environmental technologies is primarily driven by the international trade on environmentally related goods, which are categorized into three groups, namely pollution management, cleaner technologies and products, and resource management (where renewable energy belongs to) (OECD 1999). Whereas the trade on other commodities is also expected to transfer environmental technologies internationally since environmental inventions, as an interdisciplinary process, always benefit considerably from other sectors (Nemet 2012).

Positive externalities incentivize actors to behave differently from others to free ride (Franzese and Hays 2008). By engaging in international trade, countries are able to acquire environnental technologies. Cost-minimizing national governments thus tend to free ride off the environmental R\&D spending made by their counterparts in the trade partners, exactly like what they do when it comes to defence burden sharing (Murdoch and Sandler 1984; Plümper and Neumayer 2015), peacekeeping contribution (Gaibulloev et al. 2015; Passmore, Shannon, and Hart 2018), and international dispute litigation (Bechtel and Sattler 2015). Specifically, nations are expected to reduce their own environmental R\&D spending after seeing the spending increases from their trade partners. When nations make a strategic decision regarding their spending, it is impossible for them to instantly know the simultaneous decisions of others. Instead, they can only adjust their own spending according to the previous spending records of others. Thus, a nation's current spending decision regarding environmental innovation is influenced by that 
expenditures of other countries in the preceding year. Since greater bilateral trade flows bring intenser environmental technology transfers, nations are further expected to be more responsive (i.e., making more funding cut) to the increasing environmental innovation spending of their larger trade partners while being relatively insensitive to the increasing spending of their smaller trade partners.

After arguing that political costs motivate and international trade incentivize national governments to free ride off others' environmental R\&D expenditures, I make the following testable hypothesis:

Nations spend less on environmental innovation as a response to the increasing spending of their trade partners.

\section{Research Design}

\section{Sample and Outcome Variable}

My sample is restricted to OECD countries, 1982 to 2017, since only they provide high-quality, sector-specific, and cross-nationally comparable government research funding data with a good temporal coverage. Since developed countries are major investors and contributors in environmental innovation worldwide, the limited sample in this research does not undermine the meaningfulness of its finding too much. By focusing on OECD countries, I avoid introducing excessive cross-sectional heterogeneity by pooling categorically different countries together, which may confound my statistical results. My outcome variable is government spending on environmental R\&D, and I access the data from the OECD's official statistics. ${ }^{5}$ Among 34 highincome OECD members as of 2016, ${ }^{6}$ I drop Chile and Switzerland from my sample since their data have excessive missing values for undocumented reasons. After taking missing values in other countries into account (see Figure A1), my sample size is 939.

Figure 1 displays considerable spatiotemporal variation of my outcome variable. From the 1980s to 2010s, Germany and the United States always outspent the others in funding environmental $R \& D$, despite their spending patterns are irresolute, while Japan soon joined the leading camp in the 2000s. But the expenditures made by the Nordic countries, who are generally viewed as green campaigners, actually almost stagnated in the past decades. A similar

5. This is done by using the API programmed by Persson (2019).

6. So that Mexico and Turkey, two non-high-income OECD countries, are excluded. 
Figure 1: Government Environmental R\&D Expenditures of OECD Countries, 1982-2017
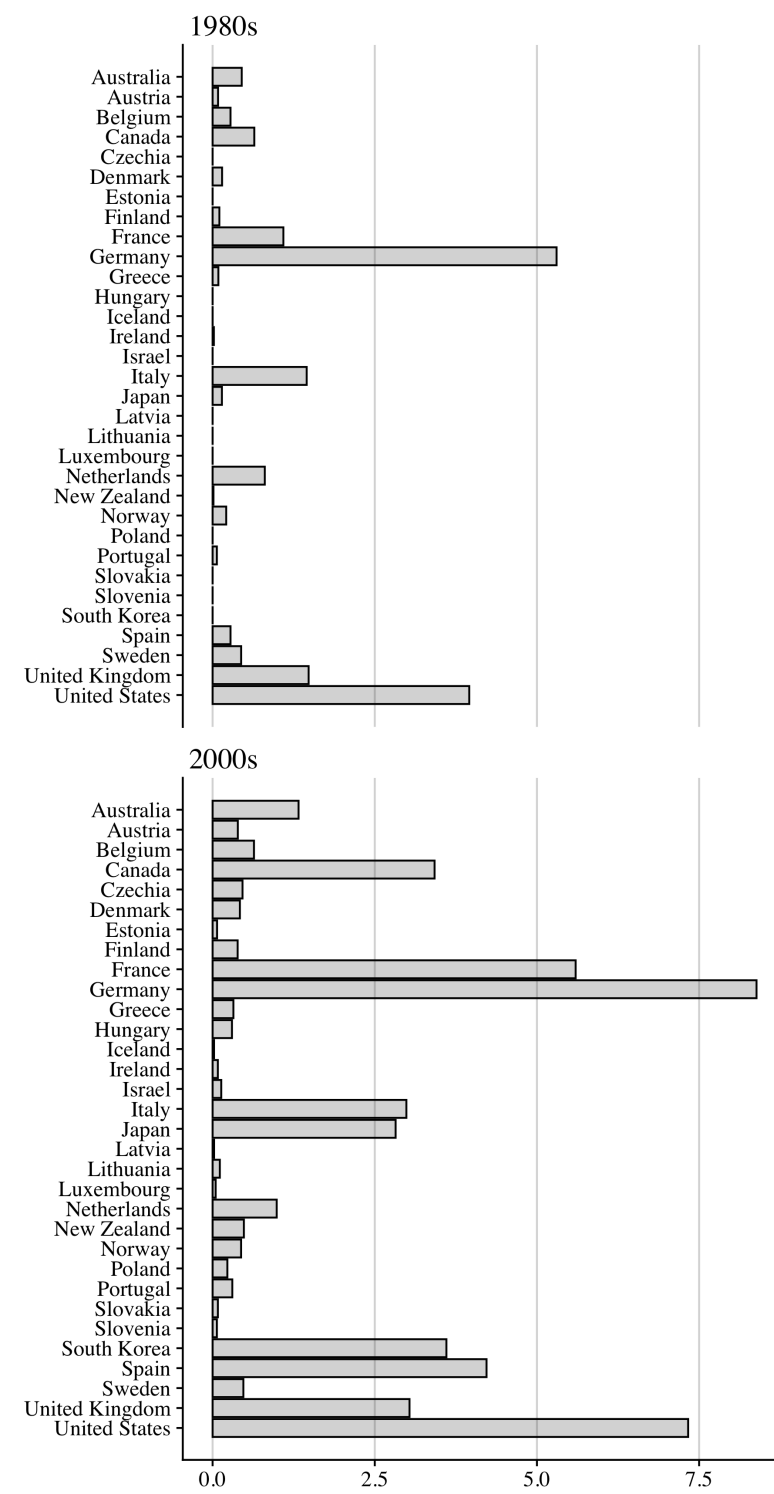

1990s

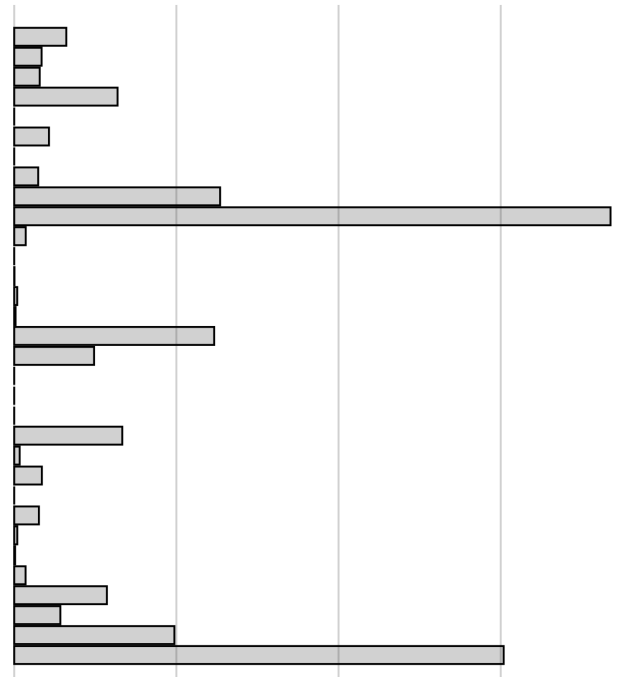

2010s

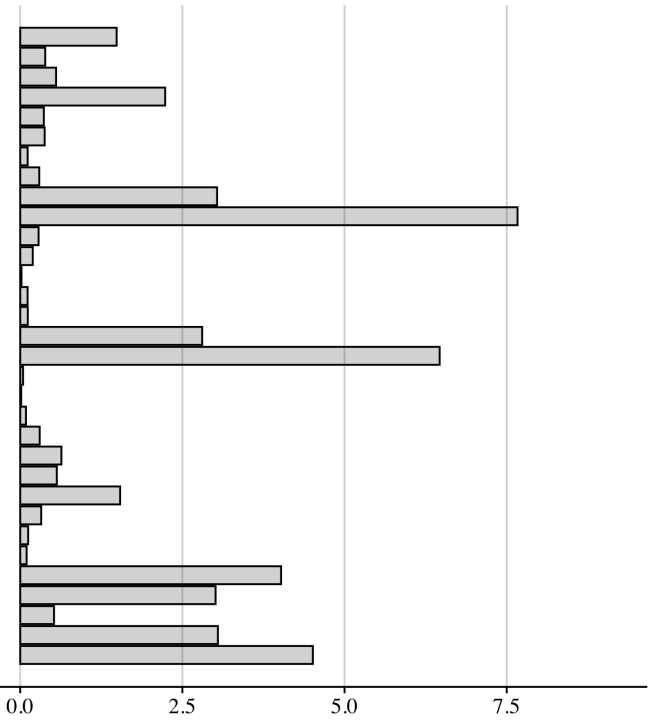

Billions US\$ 
spending stagnation is found among the Eastern European nations and Benelux as well. Although the larger economies expanded their environmental R\&D expenditures over time, the trend of their funding expansions is wavering, indicating their spending behaviours are hesitating and strategic. My argument and the descriptive evidence shown in Figure 1 suggests that the countries in my sample would have much larger government spending on environmental R\&D if they did not free ride in a counterfactual world. Therefore, I contend that my sample selection does not introduce a ceiling effect into my analysis.

The raw distribution of my outcome variable is right-skewed, which is led by the relatively larger spending of a cluster of leading countries. When free riding, although national governments are more responsive to larger environmental technology investors than to smaller ones, it is hard to argue that this responsiveness discrepancy is strictly proportional to the difference of spending sizes between larger and smaller investors. I thus use natural logarithm to transform my outcome variable, assuming that the quantitative relationship between a nation's own government environmental R\&D spending and that of others is approximately an elasticity. That is to say, nations adjust their own government environmental R\&D spending in percentage in response to the percentage change of that spending done by their trade partners.

\section{Explanatory Variable}

I use spatial regression to empirically test my hypothesis. This model operationalizes explanatory variable as the weighted outcome variable, which is called spatial lag, to quantify how an observation is influenced by others. Dictated by my argument, I use the bilateral trade volumes on environmental goods as the weights of interest. For such data, I at first access the dyadic trade flows at the chapter level, which is classified by the first two digits of the Harmonized Commodity Description and Coding System (HS) code. ${ }^{7}$ I then determine what chapters include environmental goods based on the OECD's Combined List of Environmental Goods (see Sauvage (2014) for the list). Typical example commodities which are classified as environmental goods in my data include filtering or purifying machinery and apparatus for gases, wind turbines, and photosensitive semiconductor devices. Following my argument that national governments can only respond to others' environmental innovation expenditures in the preceding rather than current year, I temporally lag my explanatory variable S-Lag by Environ-

7. These data are originally provided by the United Nations International Trade Statistics Database (UN Comtrade) while I download them through the API wrapper programmed by Vargas (2019). See Figure A2 for a discussion on missing values. I also use the aggregated trade data for robustness checks. 
mental Trade.

My explanatory varaible has a threefold interpretation. ${ }^{8}$ First, for a single nation in a given year, this variable measures how is it exposed to the previous-year government environmental R\&D expenditures of others, which are known as stimuli. Second, these stimuli are weighted by the bilateral trade volume on environmental goods between the nation and its trade partners. This feature perfectly fits my trade-proportional free riding argument. Third, the weighted stimuli are then added together to quantify the overall free riding incentive that the nation receives from its trade partners. I do not row-standardize the weights, otherwise I would make the homogeneous exposure assumption (Neumayer and Plümper 2016), meaning that all of my observations have an identical overall trade volume to all others. This assumption not only discards the contemporaneous variation of total trade flows between different countries but also ignores the fact that all countries trade more over time as globalization deepens.

\section{Control Variables}

The cross-national interdependence of government decisions is a theoretically bidirectional process (Neumayer and Plümper 2016). Although free riding is argued to prevail in how national governments decide to spend on environmental R\&D in this article, it does not exclude the possibility that the diffusion may occur simultaneously. Relegating a possible interdependence pattern to regression disturbance would induce the omitted variable bias, so it is recommended to directly measure the possible confounding interdependence process and include the corresponding variable directly in regression as a covariate (Hays, Kachi, and Franzese Jr 2010). A robust finding in the existing diffusion literature is that nations conform to norms and learn policies from their peers who are similar to themselves (see, for example, Simmons and Elkins 2004). In my case, it means that the government environmental R\&D expenditures between similar countries are likely to converge. To take this similarity-driven diffusion into account, I follow the operationalization of my explanatory variable but use the between-country similarity as the weights to create a spatial control variable. (I control the competition-driven diffusion instead for robustness.) The similarity measure is from Voeten, Strezhnev, and Bailey (2009), and it quantifies the voting record consistency between two countries at the UN General Assembly. It ranges from zero to one. Larger values are taken when a pair of countries have more identical voting records, and thus, are more similar to each other. Compared

8. I discuss and justify my explanatory variable and spatial model choice in Appendix F. 
to the commonly used sociocultural, ideological, or institutional similarity measures, the voting consistency in intergovernmental organizations better measures how similar are countries in actual and consequential policy issues. So, it better qualifies than other candidates to be a proxy to the latent between-country similarity which possibly drives the diffusion of government environmental $\mathrm{R} \& \mathrm{D}$ spending in my research context. Like my explanatory variable, this spatial control variable is not row-standardized either and temporally lagged at as well.

I also include a battery of non-spatial control variables. I use the KOF Political Globalization Index (Gygli et al. 2019) as a control variable since it considers three major types of international interactions in which a country is exposed to norms and policy information, namely diplomatic relationships, cross-national operations led by international organizations, and international nongovernmental organizations. The Index ranges from 0 to 100, and the larger the value is, the more politically globalized a country is in a given year. European Union (EU) members have to collectively meet their supernational, environmentally ambitious targets, so their spending patterns on environmental R\&D are likely to be similar. Thus, I control the binary EU Membership, which equals one if a country in a given year is an EU member. Except for these external factors, how national governments spend on environmental R\&D is also affected by their own ideological and attitudinal positions on environmental protection. I use the Comparative Manifesto Project data (Volkens et al. 2020) to control how environmentally positive an incumbent government is. Using the method of Ward and Cao (2012), specifically, I aggregate the seat share-weighted environmental protection positiveness of each party in an election and use the aggregated value to represent the incumbent's environmental position until the next election.

How reliant a country is on fossil fuel reveals the degree of carbon lock-in (Aklin and Urpelainen 2013) and the political power that environment-unfriendly industries may have, which are both likely to negatively affect the government's ability and willingness to support environmental innovation. Conversely, a country's high reliance on fossil fuel may also stimulate the environmentally progressive government to increase its support for environmental innovation even further. So, I include Fossil Fuel Rents/GDP in percentage as a control variable. The environmental Kuznets curve reveals an inversely U-shaped relationship between a nation's per capita income and environmental protection level (Grossman and Krueger 1995). The countries in my sample are all high-income economies, so they are all beyond the development-environment dilemma's tipping point. That is to say, the relationship between 
income and environmental protection is expected to be monotonically positive in these countries. I therefore control GDP per capita alone without its squared term. A country's economic performance affects how politically costly is it for the government to address environmental problems (Abou-Chadi and Kayser 2017) while how urbanized a country is partly determines the investment efficiency for the government to fund environmental innovation. In line with these two propositions, I include GDP Growth and Urban Population in percentage as control variables too. The data for the four aforementioned control variables are all from the World Banks's World Development Indicator (World Bank, n.d.). In consistence with my explanatory variable, all of these control variables are too temporally lagged.

\section{Estimation}

Since governments always adjust their expenditures based on the previous values, I include the temporally lagged dependent variable (TLDV) to take this time dependency into account. ${ }^{9}$ I also include twoway fixed effects. The inclusion of country fixed effects eliminates any timeinvariant cross-sectional heterogeneity in the baseline government environmental R\&D spending propensities. ${ }^{10}$ The inclusion of year fixed effect takes the common time trend of government environmental $R \& D$ expenditures of all countries or exogenous shocks, such as international energy crises or global climatic events, into account. For my main regression results, I apply the panel-specific Prais-Winsten feasible generalized least squares estimation, which allows the disturbance of each country to follow an unique first-order autoregressive, i.e., $\mathrm{AR}(1)$, process. I further make my standard errors robust to contemporaneous heteroskedasticity. In my robustness checks, I use different methods to account my data's spatiotemporal autocorrelation.

\section{Results}

\section{Main Finding}

Table 1 reports the main regression results. Since my right-hand side variables are measured in rather different scales, the coefficient estimates are standardized in all of my regression tables to facilitate comparisons and improve readability. I simply regress my outcome variable to the

\footnotetext{
9. See Table A3 for a panel-specific unit roots test (Im, Pesaran, and Shin 2003) which rules out the possibility that my outcome variable follows a random walk process.

10. Since my sample is large in terms of its temporal dimension, the Nickell bias is negligible substantively.
} 
Table 1: Fixed Effects Spatial Regression Results on Government Environmental R\&D Spending, OECD Countries, 1982-2017, Panel-Specific AR(1) Disturbance

\begin{tabular}{lccc}
\hline & $(1)$ & $(2)$ & $(3)$ \\
\hline TLDV & $0.674^{* * *}$ & $0.649^{* * *}$ & $0.649^{* * *}$ \\
S-Lag by Environmental Trade & $(0.038)$ & $(0.039)$ & $(0.039)$ \\
& $-0.059^{* * *}$ & $-0.050^{* * *}$ & $-0.050^{* * *}$ \\
S-Lag by Similarity & $(0.000)$ & $(0.000)$ & $(0.000)$ \\
& & 0.003 \\
Political Globalization Index (KOF) & & $(0.001)$ \\
& & 0.023 & 0.023 \\
EU Membership (Yes = 1) & $(0.003)$ & $(0.004)$ \\
& & 0.019 & 0.019 \\
Gov Environmental Position (CMP) & $(0.056)$ & $(0.056)$ \\
Fossil Fuel Rents /GDP (\%) & $0.017^{+}$ & 0.017 \\
GDP per capita & $(0.029)$ & $(0.030)$ \\
& & -0.008 & -0.008 \\
GDP Growth (\%) & $(0.016)$ & $(0.016)$ \\
& & -0.010 & -0.010 \\
Urban Population (\%) & $(0.006)$ & $(0.006)$ \\
& & 0.012 & 0.012 \\
& & $(0.008)$ & $(0.008)$ \\
Number of Observations & $-0.139^{* *}$ & $-0.139^{* *}$ \\
Root-Mean-Square Error & $(0.008)$ & $(0.008)$ \\
\hline
\end{tabular}

Variables are temporally lagged at $t-1$. Country and year fixed effects are included but not reported. Coefficient estimates are standardized.

Contemporaneous heteroskedasticity-robust standard errors are in parentheses.

${ }^{+} p<0.100,{ }^{*} p<0.050,{ }^{* *} p<0.010,{ }^{* * *} p<0.001$. 
Figure 2: Sampling Distributions of Average Spillover Effects with 95\% Percentile Intervals

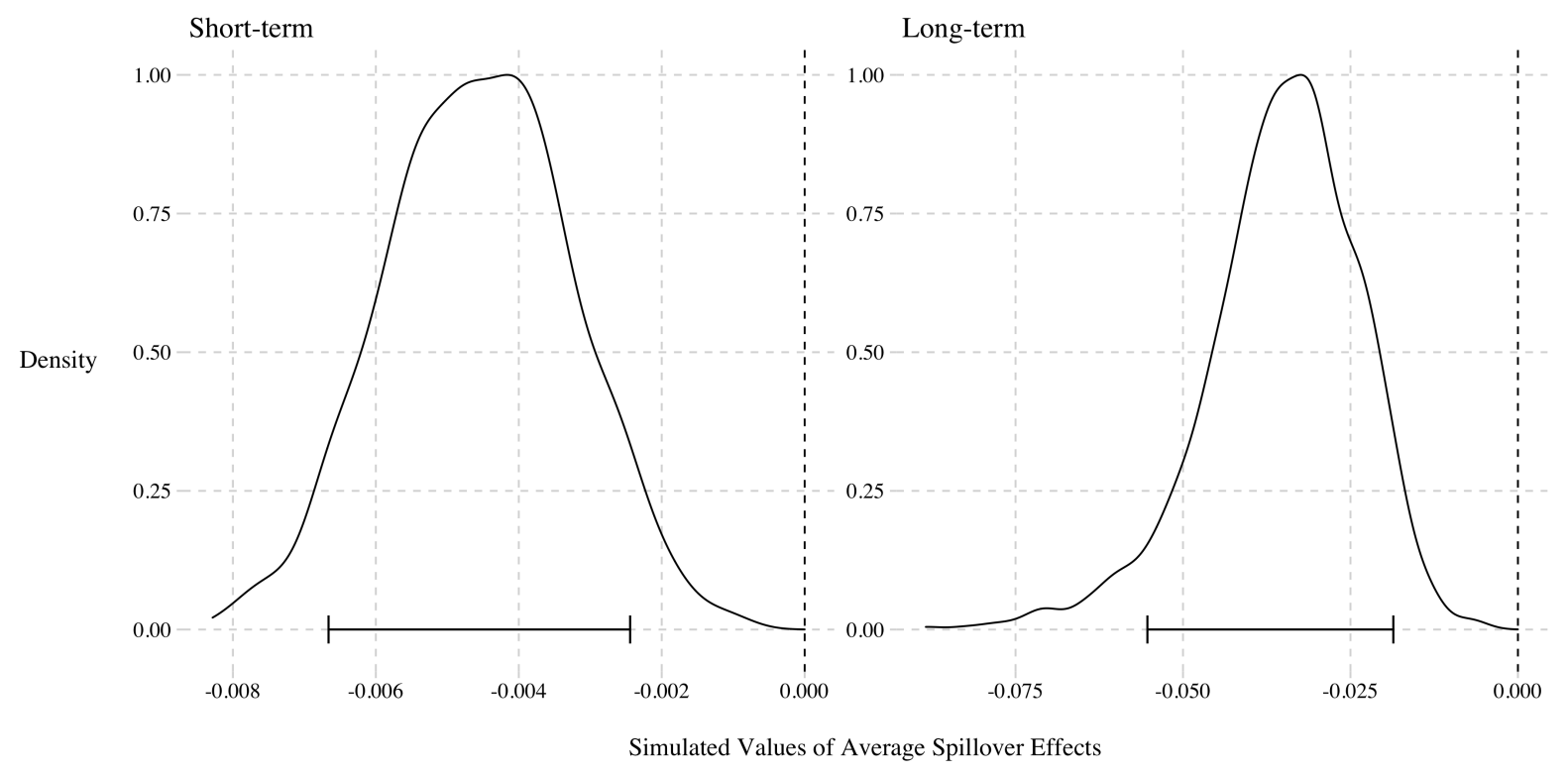

TLDV and my explanatory variable without any control variable to present the baseline results in column (1). The purpose of doing so is to be transparent regarding the concern that whether my subsequent results are simply induced by control variables (Lenz and Sahn 2020). Column (2) then incorporates a battery of non-spatial control variables, including both domestic and international factors that are likely to affect a nation's trade profile and government environmental R\&D spending simultaneously. Last, S-Lag by Similarity is further included to control the possibly concurrent diffusion in column (3), which is my complete specification.

Across the three columns, the coefficient estimates of my explanatory variable-S-Lag by Environmental Trade-are all negatively signed and thus corroborate my argument. Despite the coefficient magnitude slightly decreases as more control variables enter the estimation, the change is substantively negligible. Specifically, the negative sign means that a nation reduces its own environmental R\&D spending after seeing that its trade partners, overall, increase such expenditures in the preceding year. This spending behaviour, which deviates from what others do, indicates that national governments indeed free ride when it comes to funding environmental technologies (Franzese and Hays 2008). The coefficient estimates of my explanatory variable are all statistically significant, indicating that there is sufficient statistical evidence to reject the null hypothesis that national governments do not free ride on environmental innovation spending.

Except for overall direction and statistical significance, estimated coefficients from spatial regression models hardly tell the quantities of interest, which are the effects that countries 
receive from all of their trade partners on their own government environmental R\&D spending (spillover effects). To summarize these effects and then substantively interpret my spatial regression results, I adopt the "general approach" advocated by, among others, Whitten, Williams, and Wimpy (2021). Based upon the estimates from column (3), Table 1, I randomly draw the coefficient of S-Lag by Similarity 1,000 times. I then use these simulated coefficients to multiply the bilateral environmental trade matrix (the weights of interest), whose each row quantifies how much free riding incentive a national government is exposed to in a given year. ${ }^{11}$ Figure 2 visualizes the average row-summations of the "effect matrices," which represent the average spillover effects. The $95 \%$ percentile intervals in the two panels both fall below zero, indicating both the average short-term and long-term quantities of interest are statistically significant. The negative average short-term spillover effect means that nations immediately decrease their own government environmental R\&D spending after seeing the increasing expenditures of their trade partners in the previous year. While the considerably more sizable negative average long-term spillover effect means that trade's discouraging impact on government environmental R\&D spending accumulates over time. In other words, once national governments free ride, their environmental R\&D expenditures will be perpetually lower than that in a counterfactual world where they did not free ride. This underspending time dependency sharply contradicts with the global environmental urgency which requests countries worldwide to push a green transition as soon as possible. It should be noted that since the unit of measurement of the environmental trade data is billions US\$, the effects presented are substantively consequential.

I then use the year 2017, the latest time point in my sample, as an example to present the recipient-specific effects that nations receive from their trade partners on their own government environmental $R \& D$ spending to better situate my quantitative finding into today's global environmental protection context. The calculation is nearly identical to that used in Figure 2, but I leave each row in the "effect matrices" alone. Figure 3 visualizes these effects through four facets according their effect sizes. The more a nation trades on environmental goods, to the greater extent the nation free rides off the government environmental R\&D expenditures of its trade partners. This worrying finding is well shown in the top-left facet. It demonstrates that the strategic environmental $R \& D$ spending behaviours are mutureaders are refered to panel data spatial econometrics textbooks, such as LeSage and Pace (2009) and Elhorst (2014) 
Figure 3: Recipient-Specific Spillover Effects in 2017 with 95\% Percentile Intervals

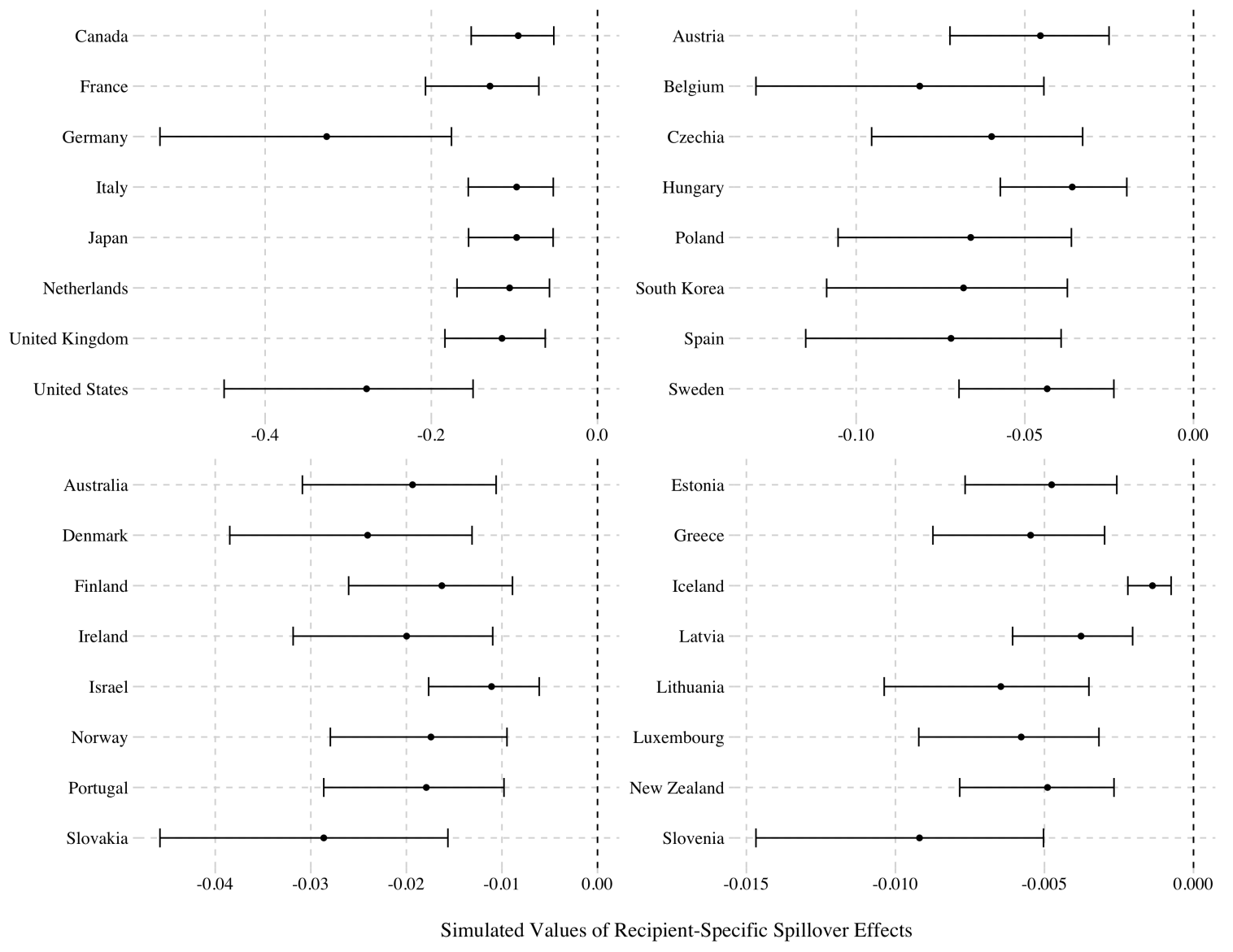


ally influenced across different countries in a symmetric way-not only latecomers but also first-movers themselves free ride. Germany and the United States are found the largest free riders on government environmental R\&D spending among OECD countries, though they are also the largest investors. These two seemingly contradictory statuses suggest that these two countries would make more contributions to the development of environmental technologies if they did not free ride. The free riding degree of Japan, another public environmental R\&D leader, is less than that of Germany and the United States. Nevertheless, the $95 \%$ percentile interval of the spending-discouraging effect that Japan receives is much narrower, indicating the stronger statistical evidence is in support of the existence of Japan's environmental R\&D free riding. South Korea, whose government environmental $R \& D$ spending rocketed since the 2000s, is a relatively relieving case. Because of the country's smaller trading size, South Korea does not free ride as much as other leading environmental technology investors do.

\section{Robustness}

In Appendix B, I keep all else constant but change how I adjust the disturbance or uncertainty estimates for accounting the data's spatiotemporal autocorrelation. I replicate Table 1 but assuming all countries share a common AR(1) parameter in Table B1. Although I explicitly include a spatial control variable in my models to account the possibly concurrent diffusion, the contemporaneous autocorrelation might still remain in my disturbance, which would lead to erroneous statistical inference as temporally serial correlation does. Since the hypothetical relationship I test happens from the preceding year to the current year, this possibility might arise when some unobserved factors drive government environmental $R \& D$ expenditures of all countries to simultaneously converge or diverge. To address this potential problem, I apply panel-corrected standard errors (Beck and Katz 1995), which are robust to disturbance's contemporaneous autocorrelation plus heteroskedasticity. The updated regression results (Table B2 and B3) are identical to my main regression results at the precision of three digits, suggesting my data's contemporaneous interdependence is already very well modelled by my regression specification.

I cluster my standard errors at the country level, an industry-standard exercise for adjusting standard errors in political science, for producing the results in Table B4. This alternative strategy enables my standard errors to be robust to intra-country serial correlation and crosscountry heteroskedasticity. In comparison with the previous analytical methods, for Table B5, 
I employ the jackknife (leave-one-out) resampling method, which is taken place at the cluster (country) level, to compute my standard errors. My explanatory variable remains statistically significant in these two tables, indicating that my finding is insensitive to different inferential methods. I further show my finding is not model-dependent through Appendix C by reproducing my estimations without the TLDV. In the four tables in Appendix C, the coefficient estimates of my explanatory variable all increase approximately twofold in terms of the magnitude. This is because the exclusion of the TLDV releases substantial explanatory power to other right-hand side variables.

Neumayer and Plümper (2017) recommend applied researchers to check how robust their results are against different weights specifications when performing spatial analysis. In Appendix D, I change my weights of interest from the bilateral trade volumes on environmental goods to the aggregated, indiscriminate bilateral trade flows. This move shows that my argument holds in a more generalized trade context. The tables in Appendix D barely have any distinguishable difference from the previous ones since the dyads who trade more on environmental goods also trade more on all commodities, and this relationship is almost linear as shown in Figure D1.

Environmental technology might be the engine for future economic growth, so countries may compete with each other on its development. In Appendix E, finally, I use the betweencountry technology competition instead of similarity as the weights in my spatial control variable to take this competition-driven diffusion into consideration. For these weights, I employ the World Bank's World Development Indicator data on the number of patent applications per year in a country to calculate the dyadic inverse technology distance. Using these alternative spatial weights for my spatial control variable does not change my results substantively.

\section{Conclusion}

In its ambitious infrastructure proposal, which is named as the American Jobs Plan, the BidenHarris Administration called on Congress to make a 35-billion investment in environmental technologies, ${ }^{12}$ the largest ever federal funding increase on R\&D outside defense. According to the theories and findings on the international diffusion of norms and policies, it would

12. The White House, March 31, 2021. https://www.whitehouse.gov/briefing-room/statements-releases/ 2021/03/31/fact-sheet-the-american-jobs-plan/, accessed May 18, 2021. 
"rally the rest of the world to meet the threat of climate change,"13 which is a key component of the Biden-Harris environmental campaign. Specifically, the socialization theory suggests that the US's strong demonstration effect and leadership in international organizations would persuade other countries to conform to the norm of generous government funding for environmental R\&D (Finnemore and Sikkink 1998). The policy learning theory and the "California effect" too indicate that the countries who have closer economic relationships to or share greater similarities with the United States would follow its massive spending plan on environmental innovation (Bennett 1991; Rose 1991; Vogel 1995, 1997). However, the influential diffusion theory in political science is established upon the assumption that what a nation does has no spillover effect on others.

In this article, I develop the free riding argument that the trade-driven technology transfer incentivizes nations to underspend on environmental innovation as a strategic response to the increasing spending of their trade partners. Using the data on government environmental R\&D expenditures and bilateral trade volumes of environmental goods from $32 \mathrm{OECD}$ countries, 1982-2017, spatial regression corroborates my argument. My finding shows under which condition diffusion ceases to happen and even flips around to divergence. It thus nullifies the optimistic expectation that green technology first-movers will encourage latercomers to expand their government expenditures on environmental innovation. What actually will happen, according to my disaggregated, country-specific analysis, is that all nations, including first-movers themselves, free ride off government environmental innovation expenditures made by their trade partners. An important policy implication from my research is that more international coordination prior to the end-of-pipe and technology deployment stages, such as multinational R\&D cooperation, is urgently needed to better, faster address the global environmental crisis.

Besides showing that the diffusion theories do not hold when externalities are present, adding a new understanding to the trade-environment nexus, and providing a strategic explanation to why national governments are reluctant to use technology-push policies to speed up green transition, this research too sheds light on two other strands of scholarship. The existing political science literature on free riding primarily focuses on how geographically proximate countries or those who are under common international frameworks (such as climate agreements, dispute settlements, or peacekeeping participation) free ride off each other. While 
I advance its research frontier by presenting a new transnational connection in which free riding may happen-international trade.

When it comes to the transnational interdepence of state behaviors and government policies, the previous studies disproportionately more focus on convergence-how closely connected countries become similar to each other-whereas largely neglect the alternative divergence. The existing literature's asymmetry is strikingly against the theoretically bidirectional nature of any interdepence process (Neumayer and Plümper 2016). Although there are a few yet notable divergence-focusing exceptions (Aklin 2016; Böhmelt and Freyburg 2015; Franzese and Hays 2006), they only specify cross-national connectivity as geographical contiguity. Thus, the scholarly understanding about how political outcomes in different countries are mutually influenced is still incomplete. This article narrows this gap by theorezing and showing that trade connectivity - the foremost politico-economic feature in a globalized era-drives government environmental efforts across different nations to diverge. Future research may consider to further explore under what mechanisms different forms of transnational connectivity may result political outcomes of interest to become cross-nationally dissimilar.

\section{References}

Abou-Chadi, Tarik, and Mark A Kayser. 2017. "It's Not Easy Being Green: Why Voters Punish Parties for Environmental Policies During Economic Downturns." Electoral Studies 45:2017.

Acemoglu, Daron, Philippe Aghion, Leonardo Bursztyn, and David Hemous. 2012. "The Environment and Directed Technical Change." American Economic Review 102 (1): 131-66.

Acemoglu, Daron, Ufuk Akcigit, Douglas Hanley, and William Kerr. 2016. "Transition to Clean Technology." Journal of Political Economy 124 (1): 52-104.

Aklin, Michaël. 2016. "Re-Exploring the Trade and Environment Nexus Through the Diffusion of Pollution." Environmental and Resource Economics 64 (4): 663-82.

Aklin, Michaël, and Johannes Urpelainen. 2013. "Political Competition, Path Dependence, and the Strategy of Sustainable Energy Transitions." American Journal of Political Science 57 (3): 643-58.

Baldwin, Elizabeth, Sanya Carley, and Sean Nicholson-Crotty. 2019. "Why Do Countries Emulate Each Others' Policies? A Global Study of Renewable Energy Policy Diffusion." World Development 120:29-45.

Bastiaens, Ida, and Evgeny Postnikov. 2017. "Greening Up: The Effects of Environmental Standards in EU and US Trade Agreements." Environmental Politics 26 (5): 847-69. 
Bechtel, Michael M, Federica Genovese, and Kenneth F Scheve. 2019. "Interests, Norms and Support for the Provision of Global Public Goods: The Case of Climate Co-operation." British Journal of Political Science 49 (4): 1333-55.

Bechtel, Michael M, and Thomas Sattler. 2015. "What is Litigation in the World Trade Organization Worth?" International Organization: 375-403.

Beck, Nathaniel, and Jonathan N Katz. 1995. "What to Do (and Not to Do) With Time-Series Cross-Section Data." American Political Science Review: 634-47.

Beise, Marian, and Klaus Rennings. 2005. "Lead Markets and Regulation: A Framework for Analyzing the International Diffusion of Environmental Innovations." Ecological Economics 52 (1): 5-17.

Bennett, Colin J. 1991. "What Is Policy Convergence and What Causes It?" British Journal of Political Science: 215-33.

Böhmelt, Tobias, and Tina Freyburg. 2015. "Diffusion of Compliance in the 'Race towards Brussels?' A Spatial Approach to EU Accession Conditionality." West European Politics 38 (3): 601-26.

BP PLC. 2020. Statistical Review of World Energy. https : //www . bp. com/content/dam/bp/busin ess-sites/en/global/corporate/xlsx/energy-economics/statistical-review/bpstats-review-2020-all-data.xlsx (accessed January 22, 2021).

Brandi, Clara, Jakob Schwab, Axel Berger, and Jean-Frédéric Morin. 2020. "Do Environmental Provisions in Trade Agreements Make Exports From Developing Countries Greener?" World Development 129:104899.

Cao, Xun, and Hugh Ward. 2015. “Winning Coalition Size, State Capacity, and Time Horizons: An Application of Modified Selectorate Theory to Environmental Public Goods Provision." International Studies Quarterly 59 (2): 264-79.

Cary, William L. 1974. "Federalism and Corporate Law: Reflections Upon Delaware." The Yale Law Journal 83 (4): 663-705.

Coe, David T, and Elhanan Helpman. 1995. "International R\&D Spillovers." European Economic Review 39 (5): 859-87.

Coe, David T, Elhanan Helpman, and Alexander W Hoffmaister. 1997. “North-South R\&D Spillovers." The Economic Journal 107 (440): 134-49.

Copeland, Brian R, and M Scott Taylor. 1994. "North-South Trade and the Environment." The Quarterly Journal of Economics 109 (3): 755-87.

De La Tour, Arnaud, Matthieu Glachant, and Yann Ménière. 2011. "Innovation and International Technology Transfer: The Case of the Chinese Photovoltaic Industry." Energy Policy 39 (2): 761-70.

Dechezleprêtre, Antoine, Matthieu Glachant, Ivan Haščič, Nick Johnstone, and Yann Ménière. 2011. "Invention and Transfer of Climate Change-Mitigation Technologies: A Global Analysis." Review of Environmental Economics and Policy 5 (1): 109-30. 
Dechezleprêtre, Antoine, Ralf Martin, and Samuela Bassi. 2019. "Climate Change Policy, Innovation and Growth." In Handbook on Green Growth, edited by Roger Fouquet, 217-39. Cheltenham, England: Edward Elgar Publishing.

Dechezleprêtre, Antoine, and Misato Sato. 2017. “The Impacts of Environmental Regulations on Competitiveness." Review of Environmental Economics and Policy 11 (2): 183-206.

Elhorst, J Paul. 2014. Spatial Econometrics: From Cross-Sectional Data to Spatial Panels. Heidelberg, Germany: Springer.

Finnemore, Martha, and Kathryn Sikkink. 1998. "International Norm Dynamics and Political Change." International Organization: 887-917.

Fischer, Carolyn, Louis Preonas, and Richard G Newell. 2017. "Environmental and Technology Policy Options in the Electricity Sector: Are We Deploying Too Many?" Journal of the Association of Environmental and Resource Economists 4 (4): 959-84.

Franzese, Robert J, and Jude C Hays. 2006. "Strategic Interaction Among EU Governments in Active Labor Market Policy-Making: Subsidiarity and Policy Coordination Under the European Employment Strategy." European Union Politics 7 (2): 167-89.

2008. "Interdependence in Comparative Politics: Substance, Theory, Empirics, Substance." Comparative Political Studies 41 (4-5): 742-80.

Gaibulloev, Khusrav, Justin George, Todd Sandler, and Hirofumi Shimizu. 2015. "Personnel Contributions to UN and Non-UN Peacekeeping Missions: A Public Goods Approach." Journal of Peace Research 52 (6): 727-42.

Gailmard, Sean, and John W Patty. 2019. "Preventing Prevention." American Journal of Political Science 63 (2): 342-52.

Grafström, Jonas, Patrik Söderholm, Erik Gawel, Paul Lehmann, and Sebastian Strunz. 2020. "Government Support to Renewable Energy R\&D: Drivers and Strategic Interactions Among EU Member States." Economics of Innovation and New Technology: 1-24.

Grossman, Gene M, and Alan B Krueger. 1995. "Economic Growth and the Environment." The Quarterly Journal of Economics 110 (2): 353-77.

Gygli, Savina, Florian Haelg, Niklas Potrafke, and Jan-Egbert Sturm. 2019. “The KOF Globalisation Index - Revisited." The Review of International Organizations 14 (3): 543-74.

Hays, Jude C, Aya Kachi, and Robert J Franzese Jr. 2010. “A Spatial Model Incorporating Dynamic, Endogenous Network Interdependence: A Political Science Application." Statistical Methodology 7 (3): 406-28.

Holzinger, Katharina, Christoph Knill, and Thomas Sommerer. 2008. “Environmental Policy Convergence: The Impact of International Harmonization, Transnational Communication, and Regulatory Competition." International Organization: 553-87.

Huber, Joseph. 2008. "Pioneer Countries and the Global Diffusion of Environmental Innovations: Theses From the Viewpoint of Ecological Modernisation Theory." Global Environmental Change 18 (3): 360-67. 
Im, Kyung So, M Hashem Pesaran, and Yongcheol Shin. 2003. "Testing for Unit Roots in Heterogeneous Panels." Journal of Econometrics 115 (1): 53-74.

IRENA. 2018. Global Energy Transformation: A Roadmap to 2050. https : / /ww . irena . org//media/Files/IRENA / Agency / Publication/2018/Apr/IRENA_Report_GET_2018.pdf (accessed January 22, 2021).

Jänicke, Martin, and Klaus Jacob. 2004. "Lead Markets for Environmental Innovations: A New Role for the Nation State." Global Environmental Politics 4 (1): 29-46.

Jinnah, Sikina, and Abby Lindsay. 2016. "Diffusion Through Issue Linkage: Environmental Norms in US Trade Agreements." Global Environmental Politics 16 (3): 41-61.

Keller, Wolfgang. 2004. "International Technology Diffusion." Journal of Economic Literature 42 (3): 752-82.

Kern, Kristine, Helge Jörgens, and Martin Jänicke. 2001. The Diffusion of Environmental Policy Innovations: A Contribution to the Globalisation of Environmental Policy. WZB Discussion Paper, No. FS II 01-302, Wissenschaftszentrum Berlin für Sozialforschung (WZB), Berlin.

Lanjouw, Jean Olson, and Ashoka Mody. 1996. "Innovation and the International Diffusion of Environmentally Responsive Technology." Research Policy 25 (4): 549-71.

Lenz, Gabriel, and Alexander Sahn. 2020. "Achieving Statistical Significance with Control Variables and without Transparency." Political Analysis: 1-14.

LeSage, James, and R. Kelley Pace. 2009. Introduction to Spatial Econometrics. Boca Raton, FL: Chapman \& Hall/CRC.

Maskus, Keith Eugene. 2004. Encouraging International Technology Transfer. UNCTAD-ICTSD Project on IPRs and Sustainable Development Issue Paper No. 7.

Murdoch, James C, and Todd Sandler. 1984. "Complementarity, Free Riding, and the Military Expenditures of NATO Allies." Journal of Public Economics 25 (1-2): 83-101.

Nemet, Gregory F. 2012. “Inter-Technology Knowledge Spillovers for Energy Technologies." Energy Economics 34 (5): 1259-70.

Neumayer, Eric, and Thomas Plümper. 2016. "W." Political Science Research and Methods 4 (1): 175-93.

—. 2017. Robustness Tests for Quantitative Research. England: Cambridge University Press.

OECD. 1999. The Environmental Goods \& Services Industry: Manual for Data Collection and Analysis. Paris: OECD Publishing. DOI: 10.1787/9789264173651-en.

2018. Mobilising Bond Markets for a Low-Carbon Transition. Green Finance and Investment Series. Paris: OECD Publishing. DOI: 10.1787/9789264308114-en.

OECD, The World Bank, and UN Environment. 2018. Financing Climate Futures: Rethinking Infrastructure. Paris: OECD Publishing. DOI: 10.1787/9789264308114-en.

Our World in Data. n.d. Annual Total $\mathrm{CO}_{2}$ Emissions, by World Region. https: //ourworldindat a. org/grapher/annual-co-emissions-by-region (accessed January 22, 2021). 
Passmore, Timothy JA, Megan Shannon, and Andrew F Hart. 2018. "Rallying the Troops: Collective Action and Self-interest in UN Peacekeeping Contributions." Journal of Peace Research 55 (3): 366-79.

Perkins, Richard, and Eric Neumayer. 2009. "Transnational Linkages and the Spillover of EnvironmentEfficiency into Developing Countries." Global Environmental Change 19 (3): 375-83.

Persson, Eric. 2019. OECD: Search and Extract Data from the OECD. R Package, Version 0.2.4. The Comprehensive R Archive Network (CRAN), https : / /CRAN . R-project . org/package= OECD.

Plümper, Thomas, and Eric Neumayer. 2015. "Free-riding in Alliances: Testing an Old Theory with a New Method." Conflict Management and Peace Science 32 (3): 247-68.

Potoski, Matthew, and Aseem Prakash. 2005. "Green Clubs and Voluntary Governance: ISO 14001 and Firms' Regulatory Compliance." American Journal of Political Science 49 (2): 23548.

Prakash, Aseem, and Matthew Potoski. 2006. "Racing to the Bottom? Trade, Environmental Governance, and ISO 14001." American Journal of Political Science 50 (2): 350-64.

. 2007. "Investing Up: FDI and the Cross-Country Diffusion of ISO 14001 Management Systems." International Studies Quarterly 51 (3): 723-44.

Rose, Richard. 1991. “What Is Lesson-Drawing?" Journal of Public Policy 11 (1): 3-30.

Saikawa, Eri. 2013. "Policy Diffusion of Emission Standards: Is There a Race to the Top." World Politics 65:1.

Sauvage, Jehan. 2014. The Stringency of Environmental Regulations and Trade in Environmental Goods. The OECD Trade and Environment Working Paper Series.

Simmons, Beth A, and Zachary Elkins. 2004. "The Globalization of Liberalization: Policy Diffusion in the International Political Economy." American political science review: 171-89.

Stokes, Leah C. 2016. “Electoral Backlash against Climate Policy: A Natural Experiment on Retrospective Voting and Local Resistance to Public Policy." American Journal of Political Science 60 (4): 958-74.

Tews, Kerstin, Per-Olof Busch, and Helge Jörgens. 2003. "The Diffusion of New Environmental Policy Instruments." European Journal of Political Research 42 (4): 569-600.

Vargas, Mauricio. 2019. tradestatistics. R Package, Version 0.2.5. GitHub, https : //github.com/ ropensci/tradestatistics.

Voeten, Erik, Anton Strezhnev, and Michael Bailey. 2009. United Nations General Assembly Voting Data. Version 27, Harvard Dataverse, DOI: 10.7910/DVN/LEJUQZ.

Vogel, David. 1995. Trading Up: Consumer and Environmental Regulation in a Global Economy. Cambridge, MA: Harvard University Press.

1997. "Trading Up and Governing Across: Transnational Governance and Environmental Protection." Journal of European Public Policy 4 (4): 556-71. 
Volkens, Andrea, Tobias Burst, Werner Krause, Pola Lehmann, Theres Matthiẽ̃̈̈, Nicolas Merz, Sven Regel, Bernhard WeÃ̈̈els, and Lisa Zehnter. 2020. The Manifesto Data Collection. Manifesto Project (MRG/CMP/MARPOR). Version 2020b, DOI: 10.25522/manifesto. mpds.2020b.

Wacziarg, Romain. 2001. "Measuring the Dynamic Gains from Trade." The World Bank Economic Review 15 (3): 393-429.

Ward, Hugh, and Xun Cao. 2012. "Domestic and International Influences on Green Taxation." Comparative Political Studies 45 (9): 1075-103.

Whitten, Guy D, Laron K Williams, and Cameron Wimpy. 2021. "Interpretation: The Final Spatial Frontier." Political Science Research and Methods 9 (1): 140-56.

World Bank. n.d. World Development Indicator. Dataset, http : / / databank . worldbank . org / data/download/WDI_csv.zip (accessed April 28, 2021).

Wright, Joseph. 2008. “To Invest or Insure? How Authoritarian Time Horizons Impact Foreign Aid Effectiveness." Comparative Political Studies 41 (7): 971-1000.

Zachmann, Georg, Amma Serwaah-Panin, and Michele Peruzzi. 2015. "When and How to Support Renewables?-Letting the Data Speak." In Green Energy and Efficiency: An Economic Perspective, edited by Alberto Ansuategi, Juan Delgado, and Ibon Galarraga, 291332. Green Energy and Technology. Berlin, Germany: Springer.

Zeng, Ka, and Josh Eastin. 2007. "International Economic Integration and Environmental Protection: The Case of China." International Studies Quarterly 51 (4): 971-95. 


\section{Appendix}

\section{Overview}

- Appendix A: Missing values, summary statistics, and a diagnostics test.

- Appendix B: Different disturbance and standard error adjustments.

- Appendix C: Estimations without the temporally lagged dependent variable (TLDV).

- Appendix D: Dyadic aggregated trade as the spatial weights of interest.

- Appendix E: Dyadic technology competition as the spatial control weights.

- Appendix F: Discussion and justification of my explanatory variable and spatial model choice. 


\section{Appendix A}

Table A1: Summary Statistics of Outcome and Non-Spatial Control Variables

\begin{tabular}{lrrrrrr}
\hline Variable & Min & Median & Max & Mean & SD & Obs \\
\hline Gov Env R\&D Spending $^{*}$ & 3.37 & 10.80 & 14.17 & 10.84 & 1.80 & 909 \\
Political Globalization Index & 36.50 & 87.31 & 98.85 & 81.13 & 15.26 & 1,090 \\
EU Membership (Yes = 1) & 0.00 & 1.00 & 1.00 & 0.54 & 0.50 & 1,087 \\
Gov Environmental Position & 0.00 & 0.59 & 3.67 & 0.78 & 0.62 & 1,042 \\
Fossil Fuel Rents/GDP (\%) & 0.00 & 0.04 & 10.88 & 0.46 & 1.18 & 1,066 \\
GDP per capita** & 3.88 & 32.10 & 111.97 & 33.69 & 18.32 & 1,064 \\
GDP Growth (\%) & -14.84 & 2.75 & 25.16 & 2.70 & 3.15 & 1,056 \\
Urban Population (\%) & 43.22 & 75.65 & 97.92 & 74.55 & 11.59 & 1,152 \\
\hline
\end{tabular}

* Thousands US\$, logged.

*** Thousands US\$. 
Table A2: Summary Statistics of Spatial Weights in Dyadic Format

\begin{tabular}{lrrrrrr}
\hline Variable & Min & Median & Max & Mean & SD & Obs \\
\hline Environmental Trade $^{*}$ & 0.00 & 0.49 & 333.26 & 4.78 & 16.77 & 33,956 \\
Aggregated Trade $^{*}$ & 0.00 & 1.12 & 685.24 & 8.91 & 29.78 & 33,378 \\
Similarity & 0.00 & 0.92 & 1.00 & 0.85 & 0.21 & 34,642 \\
Technology Competition & 0.00 & 0.00 & 1.00 & 0.00 & 0.02 & 31,406 \\
\hline
\end{tabular}

${ }^{*}$ Billions US\$.

Diagonal elements, which all equal to zero (a country is not connected with itself), are included. 
Table A3: Im-Pesaran-Shin Panel-Specific Unit Roots Test

\begin{tabular}{|c|c|c|c|}
\hline Test Statistic & $p$ & Obs & $N$ \\
\hline-5.584 & 0.000 & 862 & 32 \\
\hline \multicolumn{4}{|c|}{$H_{0}:$ All panels have a unit root. } \\
\hline \multicolumn{4}{|c|}{$\begin{array}{l}\text { Data are demeaned; time trend is included; } \\
\text { number of lags is selected by the Bayesian In- } \\
\text { formation Criterion (BIC). }\end{array}$} \\
\hline \multicolumn{4}{|c|}{$\begin{array}{l}\text { Under } H_{0} \text {, the test statistic asymptotically (as } \\
N, T \rightarrow \infty) \text { follows } \mathcal{N}(0,1) \text {. }\end{array}$} \\
\hline
\end{tabular}


Figure A1: Missing Values in Government Environmental R\&D Spending (Outcome Variale)

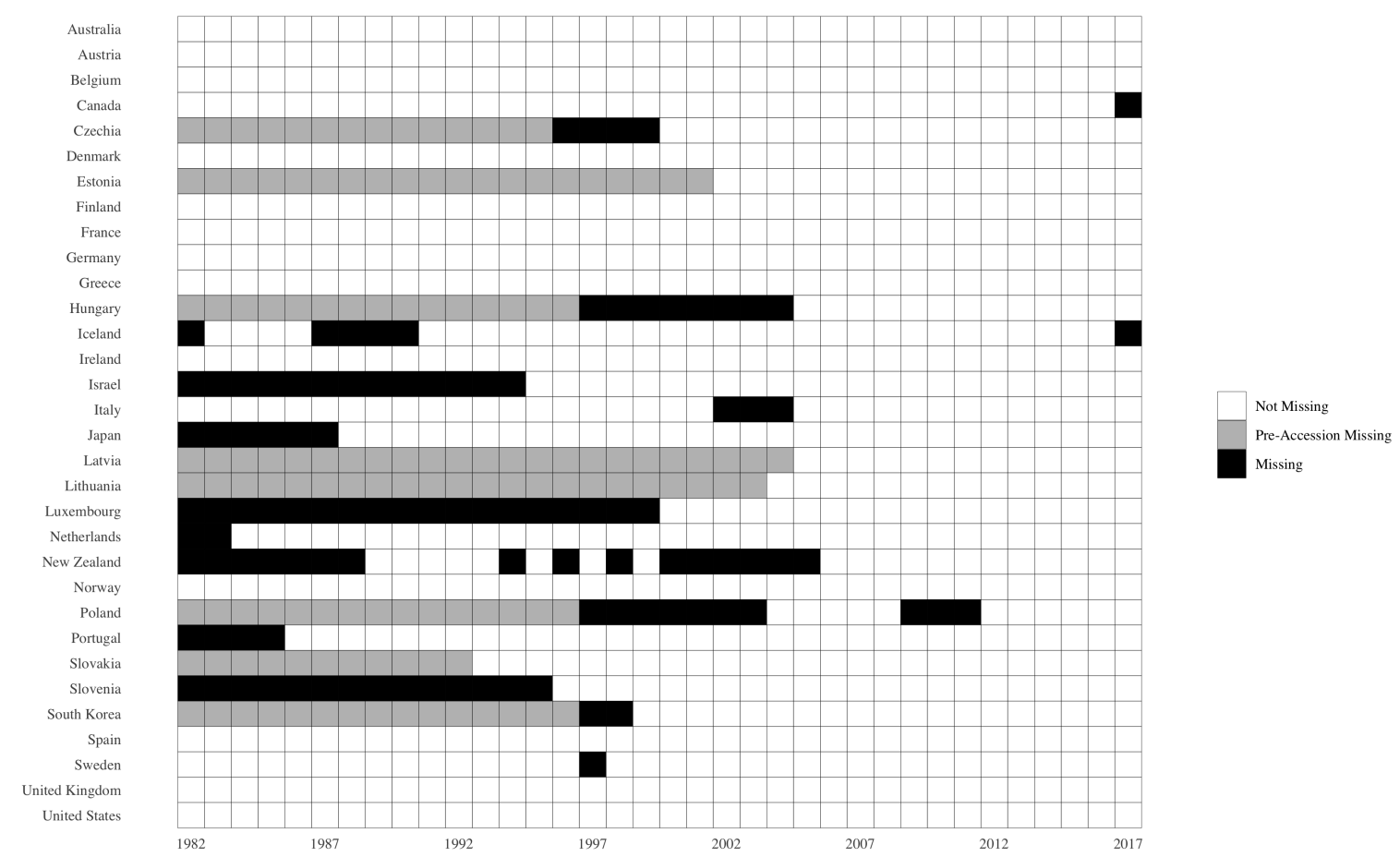

In the complete data case (i.e., no missing value), my sample size would be $N \times T=32 \times 36=1,152$. The vast majority of missing values in my outcome variable is caused by the later accessions to the OECD of South Korea and the Eastern European nations (labeled as "Pre-Accession Missing"). There is no convincing factor that may endogenize the missing-data process, so I delete the observations with missing values of outcome variable in a listwise way. After doing so, my sample size decreases to 939. 
Figure A2: Number of Missing Values in Bilateral Trade Volumes on Environmental Goods (Spatial Weights of Interest) in Each Country-Year (Unit of Analysis)

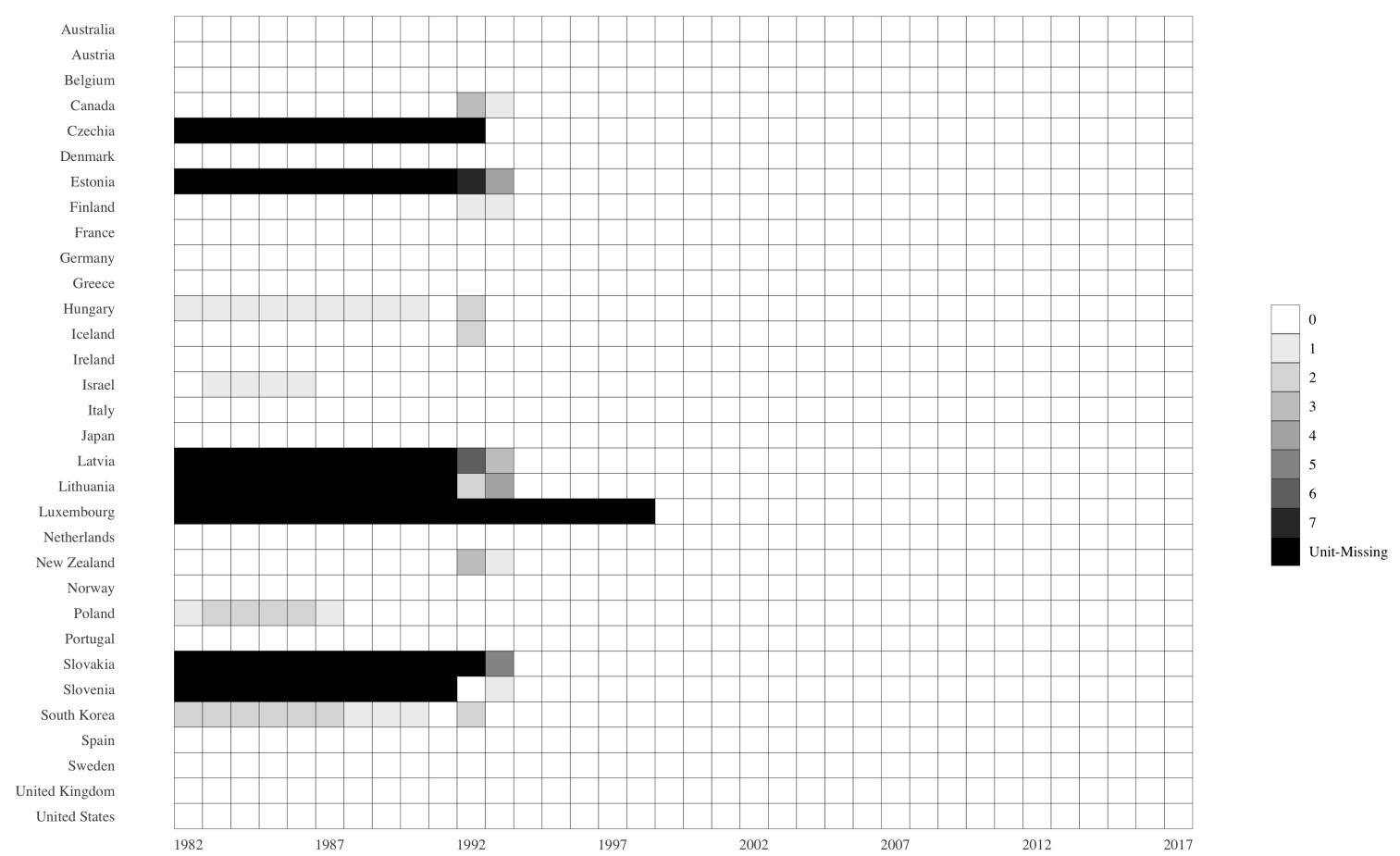

I omit the sparsely missing values in these data. Since my sample is OECD countries, no unobserved endogenous factor may convincingly govern the missing-data process. In other words, the missing at random (MAR) assumption is very likely to hold. Given that various control variables and spatiotemporal heterogeneities are included in my models, dropping the missing values has no effect on my point estimates and only minimal impact on my estimation efficiency. A missing value is labeled as "Unit-Missing" when the relevant country has no data with all others at all for a given year. Unit-missing values do not count in others' missing values. For example, the bilateral trade data between Australia and all Eastern European countries but Poland are missing for 1981, but Australia still has no missing value for that year. 


\section{Appendix B}

Table B1: Fixed Effects Spatial Regression Results on Government Environmental R\&D Spending, OECD Countries, 1982-2017, AR(1) Disturbance

\begin{tabular}{lccc}
\hline & $(1)$ & $(2)$ & $(3)$ \\
\hline TLDV & $0.675^{* * *}$ & $0.656^{* * *}$ & $0.656^{* * *}$ \\
S-Lag by Environmental Trade & $(0.041)$ & $(0.042)$ & $(0.042)$ \\
& $-0.048^{* * *}$ & $-0.049^{* * *}$ & $-0.049^{* * *}$ \\
S-Lag by Similarity & $(0.000)$ & $(0.000)$ & $(0.000)$ \\
& & -0.001 \\
Political Globalization Index (KOF) & & $(0.001)$ \\
& & 0.028 \\
EU Membership (Yes = 1) & $(0.004)$ & $(0.004)$ \\
& & 0.001 & 0.001 \\
Gov Environmental Position (CMP) & $(0.060)$ & $(0.061)$ \\
Fossil Fuel Rents /GDP (\%) & 0.014 & 0.014 \\
GDP per capita & $(0.029)$ & $(0.029)$ \\
& & -0.002 & -0.002 \\
GDP Growth (\%) & $(0.017)$ & $(0.017)$ \\
& & -0.069 & -0.069 \\
Urban Population (\%) & $(0.006)$ & $(0.006)$ \\
& & 0.024 & 0.024 \\
& & $(0.009)$ & $(0.009)$ \\
Number of Observations & -0.071 & -0.071 \\
Root-Mean-Square Error & $(0.008)$ & $(0.008)$ \\
\hline
\end{tabular}

Variables are temporally lagged at $t-1$. Country and year fixed effects are included but not reported. Coefficient estimates are standardized.

Contemporaneous heteroskedasticity-robust standard errors are in parentheses.

${ }^{+} p<0.100,{ }^{*} p<0.050,{ }^{* *} p<0.010,{ }^{* * *} p<0.001$. 
Table B2: Fixed Effects Spatial Regression Results on Government Environmental R\&D Spending, OECD Countries, 1982-2017, Panel-Specific AR(1) Disturbance and Panel-Corrected Standard Errors

\begin{tabular}{lccc}
\hline & $(1)$ & $(2)$ & $(3)$ \\
\hline TLDV & $0.674^{* * *}$ & $0.649^{* * *}$ & $0.649^{* * *}$ \\
S-Lag by Environmental Trade & $(0.050)$ & $(0.056)$ & $(0.055)$ \\
& $-0.059^{* *}$ & $-0.050^{* *}$ & $-0.050^{* *}$ \\
S-Lag by Similarity & $(0.000)$ & $(0.000)$ & $(0.000)$ \\
& & 0.003 \\
Political Globalization Index (KOF) & & $(0.001)$ \\
& & 0.023 & 0.023 \\
EU Membership (Yes = 1) & $(0.004)$ & $(0.004)$ \\
& & 0.019 & 0.019 \\
Gov Environmental Position (CMP) & $(0.063)$ & $(0.064)$ \\
& & 0.017 & 0.017 \\
Fossil Fuel Rents/GDP (\%) & $(0.034)$ & $(0.036)$ \\
GDP per capita & -0.008 & -0.008 \\
& & $(0.019)$ & $(0.020)$ \\
GDP Growth (\%) & -0.010 & -0.010 \\
& & $(0.011)$ & $(0.011)$ \\
Urban Population (\%) & 0.012 & 0.012 \\
& & $(0.013)$ & $(0.013)$ \\
& & $-0.139^{*}$ & $-0.139^{*}$ \\
Number of Observations & $(0.010)$ & $(0.010)$ \\
Root-Mean-Square Error & & 885 & 884 \\
\hline
\end{tabular}

Variables are temporally lagged at $t-1$. Country and year fixed effects are included but not reported.

Coefficient estimates are standardized.

Panel-corrected standard errors are in parentheses.

${ }^{\dagger} p<0.100,{ }^{*} p<0.050,{ }^{* *} p<0.010,{ }^{* * *} p<0.001$. 
Table B3: Fixed Effects Spatial Regression Results on Government Environmental R\&D Spending, OECD Countries, 1982-2017, AR(1) Disturbance and Panel-Corrected Standard Errors

\begin{tabular}{lccc}
\hline & $(1)$ & $(2)$ & $(3)$ \\
\hline TLDV & $0.675^{* * *}$ & $0.656^{* * *}$ & $0.656^{* * *}$ \\
S-Lag by Environmental Trade & $(0.054)$ & $(0.057)$ & $(0.057)$ \\
& $-0.048^{* *}$ & $-0.049^{* *}$ & $-0.049^{* *}$ \\
S-Lag by Similarity & $(0.000)$ & $(0.000)$ & $(0.000)$ \\
& & -0.001 \\
Political Globalization Index (KOF) & & $(0.001)$ \\
& & 0.028 \\
EU Membership (Yes = 1) & 0.027 & $(0.004)$ \\
Gov Environmental Position (CMP) & $(0.004)$ & 0.001 \\
& & 0.001 & $(0.071)$ \\
Fossil Fuel Rents/GDP (\%) & $(0.070)$ & 0.014 \\
& 0.014 & $(0.035)$ \\
GDP per capita & $(0.034)$ & -0.002 \\
& & -0.002 & $(0.025)$ \\
GDP Growth (\%) & $(0.024)$ & -0.069 \\
& & -0.069 & $(0.012)$ \\
Urban Population (\%) & $(0.011)$ & 0.024 \\
& & 0.024 & $(0.014)$ \\
& & $(0.014)$ & -0.071 \\
Number of Observations & -0.071 & $(0.009)$ \\
Root-Mean-Square Error & & $(0.009)$ & 884 \\
\hline
\end{tabular}

Variables are temporally lagged at $t-1$. Country and year fixed effects are included but not reported.

Coefficient estimates are standardized.

Panel-corrected standard errors are in parentheses.

${ }^{\dagger} p<0.100,{ }^{*} p<0.050,{ }^{* *} p<0.010,{ }^{* * *} p<0.001$. 
Table B4: Fixed Effects Spatial Regression Results on Government Environmental R\&D Spending, OECD Countries, 1982-2017, Clustered Standard Errors

\begin{tabular}{lccc}
\hline & $(1)$ & $(2)$ & $(3)$ \\
\hline TLDV & $0.706^{* * *}$ & $0.690^{* * *}$ & $0.690^{* * *}$ \\
S-Lag by Environmental Trade & $(0.046)$ & $(0.044)$ & $(0.044)$ \\
& $-0.043^{* *}$ & $-0.044^{* *}$ & $-0.045^{* *}$ \\
S-Lag by Similarity & $(0.000)$ & $(0.000)$ & $(0.000)$ \\
& & -0.001 \\
Political Globalization Index (KOF) & & $(0.001)$ \\
& & 0.024 \\
EU Membership (Yes = 1) & $(0.003)$ & $(0.003)$ \\
& & 0.000 & 0.000 \\
Gov Environmental Position (CMP) & $(0.099)$ & $(0.098)$ \\
& & 0.013 & 0.013 \\
Fossil Fuel Rents /GDP (\%) & $(0.034)$ & $(0.034)$ \\
GDP per capita & -0.002 & -0.002 \\
& & $0.017)$ & $(0.017)$ \\
GDP Growth (\%) & -0.065 & -0.065 \\
& & $(0.005)$ & $(0.005)$ \\
Urban Population (\%) & 0.024 & 0.024 \\
& & $(0.010)$ & $(0.010)$ \\
& & -0.060 & -0.060 \\
Number of Observations & $(0.015)$ & $(0.015)$ \\
Root-Mean-Square Error & & 885 & 884 \\
\hline
\end{tabular}

Variables are temporally lagged at $t-1$. Country and year fixed effects are included but not reported.

Coefficient estimates are standardized.

Country-clustered standard errors are in parentheses.

${ }^{\dagger} p<0.100,{ }^{*} p<0.050,{ }^{* *} p<0.010,{ }^{* * *} p<0.001$. 
Table B5: Fixed Effects Spatial Regression Results on Government Environmental R\&D Spending, OECD Countries, 1982-2017, Jackknife Standard Errors

\begin{tabular}{lccc}
\hline & $(1)$ & $(2)$ & $(3)$ \\
\hline TLDV & $0.706^{* * *}$ & $0.690^{* * *}$ & $0.690^{* * *}$ \\
S-Lag by Environmental Trade & $(0.049)$ & $(0.049)$ & $(0.049)$ \\
& $-0.043^{*}$ & $-0.044^{*}$ & $-0.045^{*}$ \\
S-Lag by Similarity & $(0.000)$ & $(0.000)$ & $(0.000)$ \\
& & -0.001 \\
Political Globalization Index (KOF) & & $(0.001)$ \\
& & 0.024 & 0.024 \\
EU Membership (Yes = 1) & $(0.003)$ & $(0.003)$ \\
& & 0.000 & 0.000 \\
Gov Environmental Position (CMP) & & $0.118)$ & $(0.118)$ \\
& & 0.013 & 0.013 \\
Fossil Fuel Rents /GDP (\%) & $(0.040)$ & $(0.040)$ \\
GDP per capita & -0.002 & -0.002 \\
& & $0.021)$ & $(0.022)$ \\
GDP Growth (\%) & -0.065 & -0.065 \\
& & $(0.006)$ & $(0.006)$ \\
Urban Population (\%) & 0.024 & 0.024 \\
& & $(0.011)$ & $(0.011)$ \\
& & -0.060 & -0.060 \\
Number of Observations & $(0.022)$ & $(0.022)$ \\
Root-Mean-Square Error & & 885 & 884 \\
\hline
\end{tabular}

Variables are temporally lagged at $t-1$. Country and year fixed effects are included but not reported.

Coefficient estimates are standardized.

Country-clustered jackknife standard errors are in parentheses.

${ }^{\dagger} p<0.100,{ }^{*} p<0.050,{ }^{* *} p<0.010,{ }^{* * *} p<0.001$. 


\section{Appendix C}

Table C1: Fixed Effects Spatial Regression Results on Government Environmental R\&D Spending, OECD Countries, 1982-2017, Panel-Specific AR(1) Disturbance without TLDV

\begin{tabular}{lccc}
\hline & $(1)$ & $(2)$ & $(3)$ \\
\hline S-Lag by Environmental Trade & $-0.154^{* * *}$ & $-0.124^{* * *}$ & $-0.132^{* * *}$ \\
S-Lag by Similarity & $(0.000)$ & $(0.000)$ & $(0.000)$ \\
& & -0.034 \\
Political Globalization Index (KOF) & & $(0.002)$ \\
& & 0.047 & 0.049 \\
EU Membership (Yes = 1) & $(0.005)$ & $(0.005)$ \\
& $0.084^{*}$ & $0.084^{*}$ \\
Gov Environmental Position (CMP) & $(0.132)$ & $(0.133)$ \\
& & 0.019 & 0.017 \\
Fossil Fuel Rents/GDP (\%) & $(0.044)$ & $(0.044)$ \\
& & -0.007 & -0.006 \\
GDP per capita & $(0.017)$ & $(0.017)$ \\
& & 0.114 & 0.114 \\
GDP Growth (\%) & $(0.012)$ & $(0.012)$ \\
& & 0.002 & 0.002 \\
Urban Population (\%) & & $(0.009)$ & $(0.009)$ \\
& & $-0.425^{* * *}$ & $-0.440^{* * *}$ \\
\hline Number of Observations & & $(0.020)$ & $(0.020)$ \\
Root-Mean-Square Error & 908 & 908 & 907 \\
\hline
\end{tabular}

Variables are temporally lagged at $t-1$. Country and year fixed effects (FE) are included but not reported. Coefficient estimates are standardized.

Contemporaneous heteroskedasticity-robust standard errors (SE) are in parentheses.

${ }^{+} p<0.100,{ }^{*} p<0.050,{ }^{* *} p<0.010,{ }^{* * *} p<0.001$. 
Table C2: Fixed Effects Spatial Regression Results on Government Environmental R\&D Spending, OECD Countries, 1982-2017, Panel-Specific AR(1) Disturbance and Panel-Corrected Standard Errors without TLDV

\begin{tabular}{lccc}
\hline & $(1)$ & $(2)$ & $(3)$ \\
\hline S-Lag by Environmental Trade & $-0.154^{* * *}$ & $-0.124^{* * *}$ & $-0.132^{* * *}$ \\
& $(0.000)$ & $(0.000)$ & $(0.000)$ \\
S-Lag by Similarity & & -0.034 \\
& & $(0.002)$ \\
Political Globalization Index (KOF) & & 0.049 \\
& & 0.047 & $(0.007)$ \\
EU Membership (Yes = 1) & $(0.007)$ & $0.084^{*}$ \\
& & $0.084^{*}$ & $(0.143)$ \\
Gov Environmental Position (CMP) & $(0.142)$ & 0.017 \\
& & 0.019 & $(0.051)$ \\
Fossil Fuel Rents/GDP (\%) & $(0.050)$ & -0.006 \\
& & -0.007 & $(0.016)$ \\
GDP per capita & $(0.016)$ & 0.114 \\
& & 0.114 & $(0.018)$ \\
GDP Growth (\%) & $(0.017)$ & 0.002 \\
& & 0.002 & $(0.012)$ \\
Urban Population (\%) & & $(0.012)$ & $-0.440^{* * *}$ \\
& & $-0.425^{* * *}$ & $(0.018)$ \\
\hline Number of Observations & & $(0.018)$ & 907 \\
Root-Mean-Square Error & 908 & 908 & 0.409 \\
\hline
\end{tabular}

Variables are temporally lagged at $t-1$. Country and year fixed effects (FE) are included but not reported. Coefficient estimates are standardized.

Panel-corrected standard errors (Panel-Corrected Standard Errors) are in parentheses.

${ }^{+} p<0.100,{ }^{*} p<0.050,{ }^{* *} p<0.010,{ }^{* * *} p<0.001$. 
Table C3: Fixed Effects Spatial Regression Results on Government Environmental R\&D Spending, OECD Countries, 1982-2017, Clustered Standard Errors without TLDV

\begin{tabular}{lccc}
\hline & $(1)$ & $(2)$ & $(3)$ \\
\hline S-Lag by Environmental Trade & $-0.159^{* *}$ & $-0.149^{* *}$ & $-0.164^{* *}$ \\
S-Lag by Similarity & $(0.000)$ & $(0.000)$ & $(0.000)$ \\
& & $-0.169^{\dagger}$ & $(0.003)$ \\
Political Globalization Index (KOF) & & $0.146^{*}$ \\
EU Membership (Yes = 1) & $0.137^{\dagger}$ & $(0.009)$ \\
& $(0.009)$ & -0.016 \\
Gov Environmental Position (CMP) & -0.021 & $(0.281)$ \\
& & $(0.286)$ & 0.026 \\
Fossil Fuel Rents/GDP (\%) & 0.033 & $(0.100)$ \\
& & $(0.099)$ & -0.005 \\
GDP per capita & -0.010 & $(0.043)$ \\
& & $(0.043)$ & -0.126 \\
GDP Growth (\%) & -0.113 & $(0.013)$ \\
& & $(0.013)$ & 0.032 \\
Urban Population (\%) & 0.031 & $(0.015)$ \\
& & $(0.014)$ & -0.338 \\
& & -0.348 & $(0.038)$ \\
\hline Number of Observations & & $(0.040)$ & 907 \\
Root-Mean-Square Error & 908 & 908 & 0.582 \\
\hline
\end{tabular}

Variables are temporally lagged at $t-1$. Country and year fixed effects (FE) are included but not reported. Coefficient estimates are standardized.

Country-clustered standard errors (SE) are in parentheses.

${ }^{+} p<0.100,{ }^{*} p<0.050,{ }^{* *} p<0.010,{ }^{* * *} p<0.001$. 
Table C4: Fixed Effects Spatial Regression Results on Government Environmental R\&D Spending, OECD Countries, 1982-2017, Jackknife Standard Errors without TLDV

\begin{tabular}{lccc}
\hline & $(1)$ & $(2)$ & $(3)$ \\
\hline S-Lag by Environmental Trade & $-0.159^{* *}$ & $-0.149^{*}$ & $-0.164^{*}$ \\
S-Lag by Similarity & $(0.000)$ & $(0.000)$ & $(0.000)$ \\
& & -0.169 \\
Political Globalization Index (KOF) & & $(0.004)$ \\
& & 0.137 & $0.146^{\dagger}$ \\
EU Membership (Yes = 1) & $(0.011)$ & $(0.011)$ \\
& -0.021 & -0.016 \\
Gov Environmental Position (CMP) & $(0.332)$ & $(0.326)$ \\
& & 0.033 & 0.026 \\
Fossil Fuel Rents/GDP (\%) & $(0.118)$ & $(0.117)$ \\
& & -0.010 & -0.005 \\
GDP per capita & $(0.086)$ & $(0.094)$ \\
GDP Growth (\%) & -0.113 & -0.126 \\
& & $(0.017)$ & $(0.017)$ \\
Urban Population (\%) & 0.031 & 0.032 \\
& & $(0.015)$ & $(0.016)$ \\
& & -0.348 & -0.338 \\
Number of Observations & & $(0.060)$ & $(0.058)$ \\
Root-Mean-Square Error & 908 & 908 & 907 \\
\hline
\end{tabular}

Variables are temporally lagged at $t-1$. Country and year fixed effects (FE) are included but not reported. Coefficient estimates are standardized.

Country-clustered jackknife standard errors (SE) are in parentheses.

${ }^{+} p<0.100,{ }^{*} p<0.050,{ }^{* *} p<0.010,{ }^{* * *} p<0.001$. 


\section{Appendix D}

Table D1: Aggregated Trade as Spatial Weights of Interest, Fixed Effects Spatial Regression Results on Government Environmental R\&D Spending, OECD Countries, 1982-2017, AR(1) Disturbance

\begin{tabular}{lccc}
\hline & $(1)$ & $(2)$ & $(3)$ \\
\hline Temporal-LDV & $0.661^{* * *}$ & $0.638^{* * *}$ & $0.638^{* * *}$ \\
S-Lag by Aggregated Trade & $(0.039)$ & $(0.040)$ & $(0.041)$ \\
& $-0.071^{* * *}$ & $-0.059^{* * *}$ & $-0.059^{* * *}$ \\
S-Lag by Similarity & $(0.000)$ & $(0.000)$ & $(0.000)$ \\
& & -0.001 \\
Political Globalization Index (KOF) & & $(0.001)$ \\
& & 0.022 & $(0.004)$ \\
EU Membership (Yes = 1) & $(0.004)$ & 0.008 \\
& & 0.008 & $(0.058)$ \\
Gov Environmental Position (CMP) & & $0.058)$ & 0.015 \\
& & 0.015 & $(0.030)$ \\
Fossil Fuel Rents/GDP (\%) & $(0.030)$ & -0.008 \\
& & -0.008 & $(0.016)$ \\
GDP per capita & & $-0.016)$ & $(0.006)$ \\
& & -0.013 & 0.013 \\
GDP Growth (\%) & $(0.006)$ & $(0.008)$ \\
Urban Population (\%) & & 0.013 & $-0.144^{* *}$ \\
& & $(0.008)$ & $(0.008)$ \\
\hline Number of Observations & & $-0.144^{* *}$ & 868 \\
Root-Mean-Square Error & & $(0.008)$ & 0.373 \\
\hline
\end{tabular}

Variables are temporally lagged at $t-1$. Country and year fixed effects (FE) are included but not reported. Coefficient estimates are standardized.

Contemporaneous heteroskedasticity-robust standard errors (SE) are in parentheses.

${ }^{+} p<0.100,{ }^{*} p<0.050,{ }^{* *} p<0.010,{ }^{* * *} p<0.001$. 
Table D2: Aggregated Trade as Spatial Weights of Interest, Fixed Effects Spatial Regression Results on Government Environmental R\&D Spending, OECD Countries, 1982-2017, PanelSpecific AR(1) Disturbance and Panel-Corrected Standard Errors

\begin{tabular}{lccc}
\hline & $(1)$ & $(2)$ & $(3)$ \\
\hline Temporal-LDV & $0.661^{* * *}$ & $0.638^{* * *}$ & $0.638^{* * *}$ \\
& $(0.053)$ & $(0.057)$ & $(0.057)$ \\
S-Lag by Aggregated Trade & $-0.071^{* * *}$ & $-0.059^{* *}$ & $-0.059^{* *}$ \\
& $(0.000)$ & $(0.000)$ & $(0.000)$ \\
S-Lag by Similarity & & -0.001 \\
& & $(0.001)$ \\
Political Globalization Index (KOF) & & 0.023 \\
& & 0.022 & $(0.004)$ \\
EU Membership (Yes = 1) & $(0.004)$ & 0.008 \\
& & 0.008 & $(0.067)$ \\
Gov Environmental Position (CMP) & $(0.067)$ & 0.015 \\
& & 0.015 & $(0.036)$ \\
Fossil Fuel Rents/GDP (\%) & $(0.035)$ & -0.008 \\
& & -0.008 & $(0.020)$ \\
GDP per capita & & $(0.020)$ & $(0.012)$ \\
GDP Growth (\%) & -0.013 & 0.013 \\
& & $(0.011)$ & $(0.013)$ \\
Urban Population (\%) & & 0.013 & $-0.144^{*}$ \\
& & $(0.013)$ & $(0.010)$ \\
\hline Number of Observations & & $-0.144^{*}$ & 868 \\
Root-Mean-Square Error & & $(0.010)$ & 0.373 \\
\hline
\end{tabular}

Variables are temporally lagged at $t-1$. Country and year fixed effects (FE) are included but not reported. Coefficient estimates are standardized.

Panel-corrected standard errors (Panel-Corrected Standard Errors) are in parentheses.

${ }^{+} p<0.100,{ }^{*} p<0.050,{ }^{* *} p<0.010,{ }^{* * *} p<0.001$. 
Table D3: Aggregated Trade as Spatial Weights of Interest, Fixed Effects Spatial Regression Results on Government Environmental R\&D Spending, OECD Countries, 1982-2017, Clustered Standard Errors

\begin{tabular}{lccc}
\hline & $(1)$ & $(2)$ & $(3)$ \\
\hline Temporal-LDV & $0.697^{* * *}$ & $0.682^{* * *}$ & $0.682^{* * *}$ \\
S-Lag by Aggregated Trade & $(0.047)$ & $(0.046)$ & $(0.046)$ \\
& $-0.048^{* *}$ & $-0.049^{* *}$ & $-0.050^{* *}$ \\
S-Lag by Similarity & $(0.000)$ & $(0.000)$ & $(0.000)$ \\
& & -0.002 \\
Political Globalization Index (KOF) & & $(0.001)$ \\
& & 0.023 \\
EU Membership (Yes = 1) & 0.023 & $(0.003)$ \\
Gov Environmental Position (CMP) & & $-0.003)$ & $(0.104)$ \\
& & -0.008 & 0.011 \\
Fossil Fuel Rents/GDP (\%) & $(0.105)$ & $(0.034)$ \\
GDP per capita & 0.011 & -0.002 \\
& & $(0.034)$ & $(0.017)$ \\
GDP Growth (\%) & -0.002 & -0.070 \\
& & $(0.017)$ & $(0.005)$ \\
Urban Population (\%) & -0.070 & 0.026 \\
& & $(0.005)$ & $(0.010)$ \\
& & 0.025 & -0.062 \\
Number of Observations & $(0.010)$ & $(0.015)$ \\
Root-Mean-Square Error & & -0.062 & 868 \\
\hline
\end{tabular}

Variables are temporally lagged at $t-1$. Country and year fixed effects (FE) are included but not reported. Coefficient estimates are standardized.

Country-clustered standard errors (SE) are in parentheses.

${ }^{+} p<0.100,{ }^{*} p<0.050,{ }^{* *} p<0.010,{ }^{* * *} p<0.001$. 
Table D4: Aggregated Trade as Spatial Weights of Interest, Fixed Effects Spatial Regression Results on Government Environmental R\&D Spending, OECD Countries, 1982-2017, Jackknife Standard Errors

\begin{tabular}{lccc}
\hline & $(1)$ & $(2)$ & $(3)$ \\
\hline Temporal-LDV & $0.697^{* * *}$ & $0.682^{* * *}$ & $0.682^{* * *}$ \\
S-Lag by Aggregated Trade & $(0.050)$ & $(0.051)$ & $(0.051)$ \\
& $-0.048^{*}$ & $-0.049^{*}$ & $-0.050^{*}$ \\
S-Lag by Similarity & $(0.000)$ & $(0.000)$ & $(0.000)$ \\
& & -0.002 \\
Political Globalization Index (KOF) & & $(0.001)$ \\
EU Membership (Yes = 1) & & 0.023 \\
& & 0.023 & $(0.003)$ \\
Gov Environmental Position (CMP) & & $0.003)$ & -0.008 \\
& & -0.008 & $(0.124)$ \\
Fossil Fuel Rents/GDP (\%) & $(0.125)$ & 0.011 \\
& & 0.011 & $(0.040)$ \\
GDP per capita & $(0.040)$ & -0.002 \\
& & -0.002 & $(0.022)$ \\
GDP Growth (\%) & $(0.021)$ & -0.070 \\
& & -0.070 & $(0.007)$ \\
Urban Population (\%) & $(0.007)$ & 0.026 \\
& & 0.025 & $(0.011)$ \\
& & $(0.011)$ & -0.062 \\
Number of Observations & -0.062 & $(0.023)$ \\
Root-Mean-Square Error & & $(0.023)$ & 868 \\
\hline
\end{tabular}

Variables are temporally lagged at $t-1$. Country and year fixed effects (FE) are included but not reported. Coefficient estimates are standardized.

Country-clustered jackknife standard errors (SE) are in parentheses.

${ }^{\dagger} p<0.100,{ }^{*} p<0.050,{ }^{* *} p<0.010,{ }^{* * *} p<0.001$. 
Figure D1: Relationship Between Aggregated Trade and Environmental Trade, Bilateral Volumes

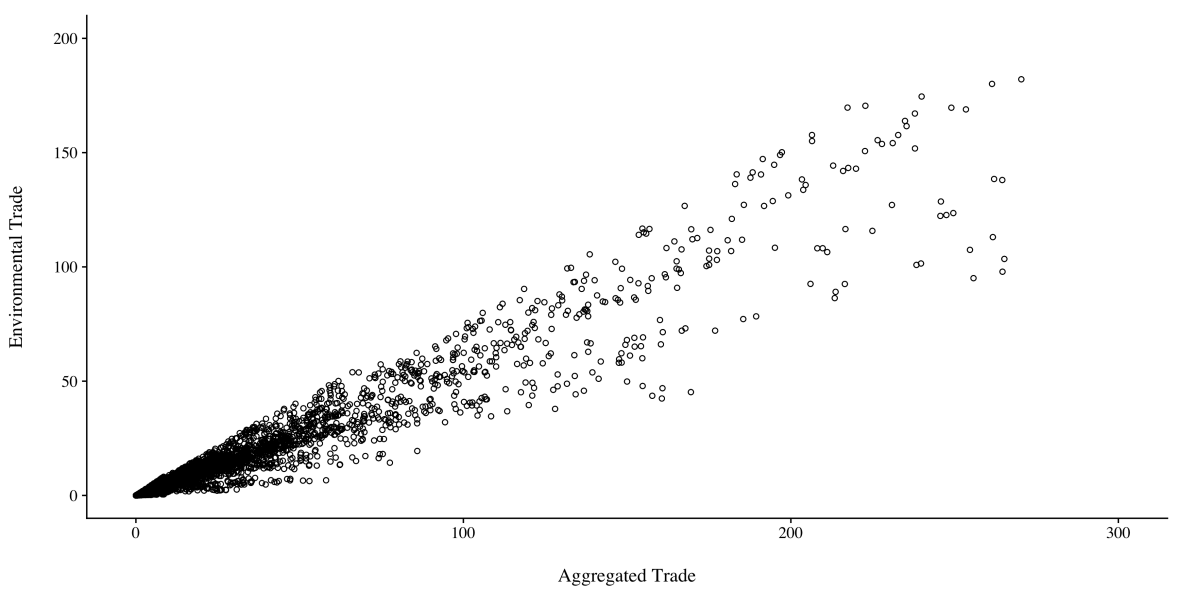

Unit of measurement is billions US\$. Observations with $x>300$ or $y>200$ are dropped for aesthetics. 


\section{Appendix E}

Table E1: Technology Competition as Spatial Control Weights, Fixed Effects Spatial Regression Results on Government Environmental R\&D Spending, OECD Countries, 1982-2017

\begin{tabular}{lcc}
\hline & $(1)$ & $(2)$ \\
& Clustered Standard Errors & AR(1) Error \\
\hline Temporal-LDV & $0.681^{* * *}$ & $0.721^{* * *}$ \\
& $(0.039)$ & $(0.039)$ \\
S-Lag by Environmental Trade & $-0.031^{*}$ & $-0.031^{*}$ \\
S-Lag by Technology Competition & $(0.000)$ & $(0.000)$ \\
& 0.017 & $0.017^{\dagger}$ \\
Political Globalization Index (KOF) & $(0.031)$ & $(0.017)$ \\
& 0.011 & 0.010 \\
EU Membership (Yes = 1) & $(0.004)$ & $(0.002)$ \\
& $0.026^{\dagger}$ & 0.007 \\
Gov Environmental Position (CMP) & $(0.056)$ & $(0.095)$ \\
& $0.020^{*}$ & 0.014 \\
Fossil Fuel Rents/GDP (\%) & $(0.028)$ & $(0.032)$ \\
& -0.001 & 0.009 \\
GDP per capita & $(0.015)$ & $(0.017)$ \\
& $-0.130^{*}$ & $-0.131^{*}$ \\
GDP Growth (\%) & $(0.005)$ & $(0.006)$ \\
& 0.014 & 0.020 \\
Urban Population (\%) & $(0.008)$ & $(0.012)$ \\
& $-0.134^{* *}$ & -0.052 \\
Number of Observations & $(0.008)$ & $(0.014)$ \\
Root-Mean-Square Error & 831 & 831 \\
\hline
\end{tabular}

Variables are temporally lagged at $t-1$. Country and year fixed effects (FE) are included but not reported. Coefficient estimates are standardized.

Standard errors (SE) are in parentheses.

${ }^{\dagger} p<0.100,{ }^{*} p<0.050,{ }^{* *} p<0.010,{ }^{* * *} p<0.001$. 
Table E2: Aggregated Trade as Spatial Weights of Interest and Technology Competition as Spatial Control Weights, Fixed Effects Spatial Regression Results on Government Environmental R\&D Spending, OECD Countries, 1982-2017

\begin{tabular}{lcc}
\hline & $(1)$ & $(2)$ \\
& Clustered Standard Errors & AR(1) Error \\
\hline Temporal-LDV & $0.672^{* * *}$ & $0.714^{* * *}$ \\
S-Lag by Aggregated Trade & $(0.040)$ & $(0.041)$ \\
& $-0.040^{* *}$ & $-0.036^{*}$ \\
S-Lag by Technology Competition & $(0.000)$ & $(0.000)$ \\
& 0.016 & $0.016^{\dagger}$ \\
Political Globalization Index (KOF) & $(0.031)$ & $(0.017)$ \\
& 0.011 & 0.010 \\
EU Membership (Yes = 1) & $(0.004)$ & $(0.003)$ \\
& 0.017 & 0.000 \\
Gov Environmental Position (CMP) & $(0.059)$ & $(0.102)$ \\
& $0.018^{\dagger}$ & 0.012 \\
Fossil Fuel Rents/GDP (\%) & $(0.028)$ & $(0.032)$ \\
& -0.002 & 0.008 \\
GDP per capita & $(0.016)$ & $(0.017)$ \\
& $-0.136^{*}$ & $-0.139^{*}$ \\
GDP Growth (\%) & $(0.006)$ & $(0.006)$ \\
& 0.015 & 0.021 \\
Urban Population (\%) & $(0.008)$ & $(0.012)$ \\
& $-0.138^{* *}$ & -0.052 \\
Number of Observations & $(0.008)$ & $(0.014)$ \\
Root-Mean-Square Error & 816 & 816 \\
\hline
\end{tabular}

Variables are temporally lagged at $t-1$. Country and year fixed effects (FE) are included but not reported. Coefficient estimates are standardized.

Standard errors (SE) are in parentheses.

${ }^{\dagger} p<0.100,{ }^{*} p<0.050,{ }^{* *} p<0.010,{ }^{* * *} p<0.001$. 


\section{Appendix F}

In matrix notation, my explanatory variable is generically written as $\mathbf{W y}$, in which $\mathbf{W}$ is a $N T \times N T$ block diagonal weights matrix and $\mathbf{y}$ is the column vector of the outcome variable at length $N T$. By temporally lagging it at $t-1$, my regression becomes the temporally lagged spatial lag (TLSL) model (Wimpy, Williams, and Whitten, forthcoming). In scalar notation, each observation in my explanatory variable equals $\sum_{j=1}^{N} \operatorname{trade}_{i, j, t-1} \times y_{j, t-1}(i \neq j)$, the year 1981 is $t_{0}$.

Some applied researchers use the TLSL model to circumvent the simultaneity bias in the spatial autoregressive (SAR) model. Nevertheless, the decision of temporally lagging my explanatory variable in this research is completely theory-driven, as main text justifies. Actually, Wimpy, Williams, and Whitten illustrates that the TLSL model shall be better viewed as a variant of the spatial-X (SLX) model rather than a variant of the SAR model. The former one is, in general, more theoretically justifiable and empirically flexible than the latter in political science applications (Drolc, Gandrud, and Williams 2019; Wimpy, Williams, and Whitten, forthcoming). For example, when a contiguity weights matrix is supplied, the SLX model does not automatically assume the existence of global effects, but at the same time, researchers who argue higher order effects exist are also able to incorporate them easily. Rüttenauer (forthcoming) uses Monte Carlo simulations to show that the SLX model outperforms other spatial models in terms the bias of spillover effects. Halleck Vega and Elhorst (2015) provide an interdisciplinary overview on the SLX model. Whitten, Williams, and Wimpy (2021) also discuss it from a political science perspective. It is acknowledged that temporally lagging my explanatory variable makes an assumption about the initial value's stochasticity (Franzese and Hays 2007). Also, a necessary condition for causation when explanatory variable is temporally lagged is that disturbance should not be serially correlated. Thus, I don't mean to make a causal claim by simply taking a temporal lag on my explanatory variable. On this point, see Franzese and Hays (2007) for an illustration in spatial data and Bellemare, Masaki, and Pepinsky (2017) for a more general treatment.

\section{Appendix References}

Bellemare, Marc F, Takaaki Masaki, and Thomas B Pepinsky. 2017. “Lagged Explanatory Variables and the Estimation of Causal Effect." The Journal of Politics 79 (3): 949-63. 
Drolc, Cody A, Christopher Gandrud, and Laron K Williams. 2019. “Taking Time (and Space) Seriously: How Scholars Falsely Infer Policy Diffusion from Model Misspecification." Policy Studies Journal.

Franzese, Robert J, and Jude C Hays. 2007. "Spatial Econometric Models of Cross-Sectional Interdependence in Political Science Panel and Time-Series-Cross-Section Data." Political Analysis: 140-64.

Halleck Vega, Solmaria, and J Paul Elhorst. 2015. "The SLX Model." Journal of Regional Science 55 (3): 339-63.

Rüttenauer, Tobias. Forthcoming. "Spatial Regression Models: A Systematic Comparison of Different Model Specifications Using Monte Carlo Experiments." Sociological Methods $\mathcal{E}$ Research.

Whitten, Guy D, Laron K Williams, and Cameron Wimpy. 2021. "Interpretation: The Final Spatial Frontier." Political Science Research and Methods 9 (1): 140-56.

Wimpy, Cameron, Laron K. Williams, and Guy D. Whitten. Forthcoming. "X Marks the Spot: Unlocking the Treasure of Spatial-X Models." The Journal of Politics. 